\title{
Modelling soil carbon and nitrogen cycles during land use
}

\section{change: A Review}

\author{
J. Batlle-Aguilar ${ }^{1,3}$, A. Brovelli ${ }^{1}$, A. Porporato ${ }^{1,2}$, D.A. Barry ${ }^{1, *}$ \\ ${ }^{1}$ Institute for Environmental Engineering, École Polytechnique Fédérale de Lausanne, Station 2, CH- \\ 1015, Lausanne, Switzerland. Emails: alessandro.brovelli@epfl.ch, amilcare.porporato@epfl.ch, an- \\ drew.barry@epfl.ch \\ ${ }^{2}$ Permanent address: Civil and Environmental Engineering Department, Duke University, Durham, \\ NC 27708, USA. Email: amilcare@pratt.duke.edu \\ ${ }^{3}$ Currently at National Centre for Groundwater Research and Training (NCGRT), School of the Envi- \\ ronment, Flinders University, GPO Box 2100, Adelaide, SA-5001, Australia. Email: \\ jordi.batlleaguilar@flinders.edu.au \\ * Corresponding author \\ Ph.: +41 (0) 216935576 \\ Fax: +41 (0) 216935670
}




\begin{abstract}
Forested soils are being increasingly transformed to agricultural fields in response to growing demands for food crop. This modification of the land use is known to result in deterioration of soil properties, in particular its fertility. To reduce the impact of the human activities and mitigate their effects on the soil, it is important to understand the factors responsible for the modification of soil properties. In this paper we reviewed the principal processes affecting soil quality during land use changes, focusing in particular on the effect of soil moisture dynamics on soil carbon $(\mathrm{C})$ and nitrogen $(\mathrm{N})$ cycles. Both physical and biological processes, including degradation of litter and humus, and soil moisture evolution at the diurnal and seasonal time scales were considered, highlighting the impact of hydroclimatic variability on nutrient turnover along with the consequences of land use changes from forest to agricultural soil and vice-versa.
\end{abstract}

In order to identify to what extent different models are suitable for long-term predictions of soil turnover, and to understand whether some simulators are more suited to specific environmental conditions or ecosystems, we enumerated the principal features of the most popular existing models dealing with $\mathrm{C}$ and $\mathrm{N}$ turnover. Among these models, we considered in detail a mechanistic compartment-based model. To show the capabilities of the model and to demonstrate how it can be used as a predictive tool to forecast the effects of land use changes on $\mathrm{C}$ and $\mathrm{N}$ dynamics, four different scenarios were studied, intertwining two different climate conditions (with and without seasonality) with two contrasting soils having physical properties that are representative of forest and agricultural soils. The model incorporates synthetic time series of stochastic precipitation, and therefore soil moisture evolution through time. Our main findings in simulating these scenarios are that 1) forest soils have higher concentrations of $\mathrm{C}$ and $\mathrm{N}$ than agricultural soils as a result of higher litter decomposition; 2) high frequency changes in water saturations under seasonal climate scenarios are commensurate with $\mathrm{C}$ and $\mathrm{N}$ concentrations in agricultural soils; and 3) due to their different physical properties, forest soils 
attenuate the seasonal climate-induced frequency changes in water saturation, with accompanying changes in $\mathrm{C}$ and $\mathrm{N}$ concentrations. The model was shown to be capable of simulating the long term effects of modified physical properties of agricultural soils, being thus a promising tool to predict future consequences of practices affecting sustainable agriculture, such as tillage (leading to erosion), ploughing, harvesting, irrigation and fertilization, leading to $\mathrm{C}$ and $\mathrm{N}$ turnover changes and in consequence, in terms of agriculture production.

Keywords: soil organic matter; biogeochemical cycles; agricultural soil; forest soil; soil nutrients; soil moisture dynamics; soil restoration. 
Contents

1 INTRODUCTION...................................................................................................................................

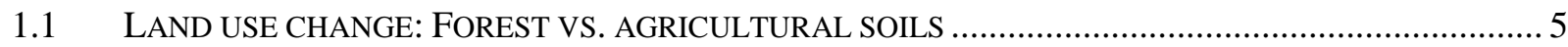

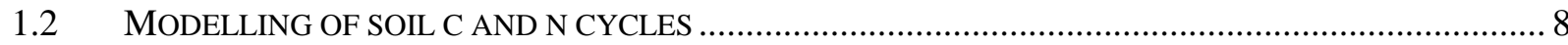

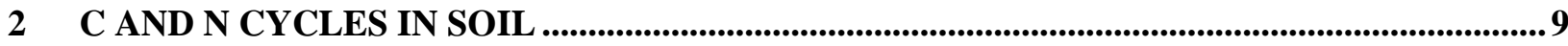

3 MOISTURE DYNAMICS AS A CONTROLLING FACTOR OF SOIL CARBON AND

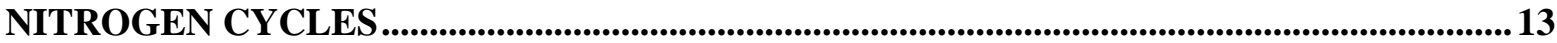

4 EXISTING MODELS OF SOIL CARBON AND NITROGEN TURNOVER ..........................16

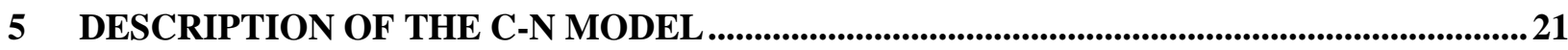

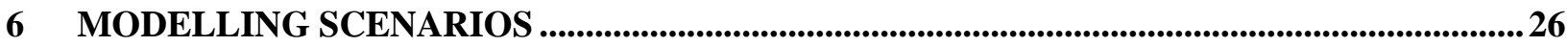

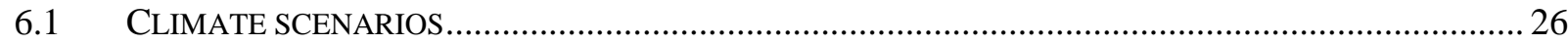

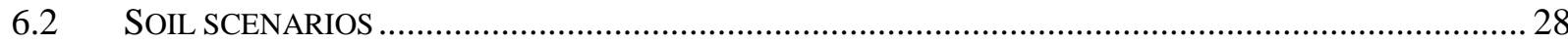

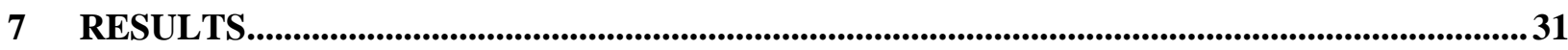

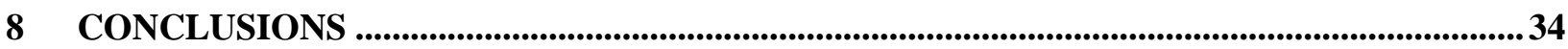

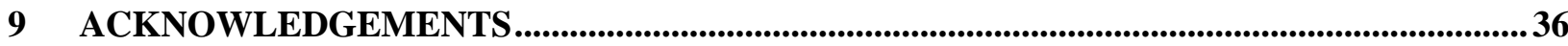

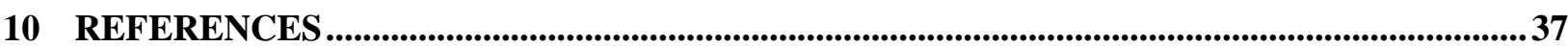

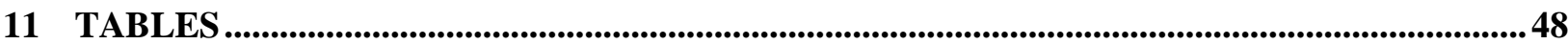

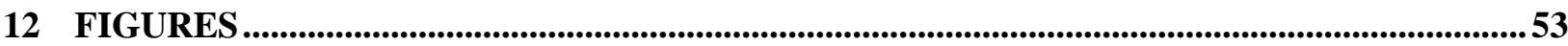




\section{Introduction}

Soils are complex systems sustaining life on Earth. Among other functions, soils maintain plant and animal growth, recycle nutrients and organic wastes, filter and purify water. Precisely, soil quality refers to a combination of chemical, physical, and biological processes that confers to the soil the ability to carry out, among others, these particular ecological functions. Numerous human activities however utilise soil, modify its physical and chemical properties and change the composition of its ecosystems. As a result, in the last century a widespread decrease of soil quality has been observed, together with a deterioration of its functioning (Brady and Weil, 2004).

The main component of soils is organic matter (SOM), which shows a variable degree of decomposition, from fresh litter to highly decomposed humus. SOM stores three to four times the amount of carbon (C) than found in all living vegetation. Other than $\mathrm{C}$, soils also contain nearly all the macro(nitrogen, $\mathrm{N}$, phosphorous, $\mathrm{P}$, and potassium, $\mathrm{K}$ ) and micro-nutrients required by living organisms. Among the macronutrients $\mathrm{N}$ plays a major role since it is essential for life but its bio-available forms are seldom abundant in the environment. Therefore in many ecosystems the $\mathrm{N}$ cycle controls the overall soil turnover and functioning. For these reasons and without neglecting the importance of other nutrients, in this paper the focus is on soil $\mathrm{C}$ and $\mathrm{N}$ cycles.

\subsection{Land use change: Forest versus agricultural soils}

The increasing demand on food crops, pasture, firewood and timber is at the origin of worldwide changes of land-use in forested areas. This situation is worrying in some areas of the planet, such as South America, where $12 \%$ and $7 \%$ of forestland was converted to pasture and croplands, respectively, between 1850 and 1985 (Houghton et al., 1991). Land-use changes, and especially cultivation of previously forested land, reduce significantly the soil quality (e.g., changes in SOM content and decomposition rates, changes in soil chemical and physical properties), leading to a permanent degrada- 
tion of land productivity (Nye and Greenland, 1964; Islam et al., 1999). Furthermore, it has been reported that deforestation increases carbon dioxide $\left(\mathrm{CO}_{2}\right)$ release to the atmosphere (Houghton, 2002), which contributes to global warming.

All studies that focused on the effects of land conversion from forest to cultivated land concluded that land-use change induces a reduction of the available soil $\mathrm{C}$ and a decrease in its quality. The maximum rate of loss occurs during the first $10 \mathrm{y}$ of cultivation, with total $\mathrm{C}$ decrease up to $30 \%$ (Davidson and Ackerman, 1993; Lugo and Brown, 1993; Murty et al., 2002) followed by reduced but still significant reduction rate (Brams, 1971; Martins et al., 1991; Bonde et al., 1992; Motavalli et al., 2000). Furthermore, it was reported that the loss rate is highly variable and influenced by several factors such as the native vegetation, climate, soil type and management practices (Mann, 1986; Davidson and Ackerman, 1993; Bruce et al., 1999).

Contrasting with the conversion from forest to cultivated land, controversy exists when the change is from forest to pasture lands. The overall change in soil $\mathrm{C}$ has been shown to be either positive or negative. For instance, de Moraes et al. (1996) found an increase up to $20 \%$ in total soil C 20 y after the change in land use, while Veldkamp (1994) reported a net soil organic C loss up to $18 \%$ after $25 \mathrm{y}$. Johnson (1992) also observed that changes in soil C in both land-use cultivation and pasture were associated with changes in soil N. Reiners et al. (1994) found that the transformation of forest land to pasture led to important changes in the $\mathrm{N}$ cycling. For example, the ammonium $\left(\mathrm{NH}_{4}^{+}\right)$pool was larger in pasture lands while the nitrate $\left(\mathrm{NO}_{3}^{-}\right)$pool was less important in pasture than forest lands. This is consistent with a low rate of plant uptake of $\mathrm{NH}_{4}^{+}$and slow nitrification rates (Vitousek, 1984; Vitousek and Sanford, 1986).

One of the important aspects that affect SOM cycling in the transition from forest to cultivated soil is the removal of most of the fresh organic C (litter) due to harvesting (Smil, 1999). However, harvest- 
ing is not the only factor responsible for the soil organic $\mathrm{C}$ loss. Some other processes that were also recognized to contribute to change the amount of soil $\mathrm{C}$ are the changes in litter chemical properties (Feigl et al., 1995; Ellert and Gregorich, 1996; Scholes et al., 1997), soil type (Feller and Beare, 1997; Scholes et al., 1997; García-Oliva et al., 1999), microbial community (Prasad et al., 1995), changes in soil N cycling (Dalal and Mayeer, 1986; Brown and Lugo, 1990; Desjardins et al., 1994) and management practices (Feller and Beare, 1997; Fernandes et al., 1997; Bruce et al., 1999). Soil tillage and ploughing promote redistribution of residues and their decomposition. As a result, soil $\mathrm{C}$ and $\mathrm{N}$ pools are depleted and soil fertility is lost. Soil $\mathrm{C}$ is oxidized to $\mathrm{CO}_{2}$ and lost to the atmosphere contributing to the increase of greenhouse gases in the atmosphere. Moreover, tillage improves soil aeration, destroys macro-aggregates and changes the hydrological cycle, with an increase of the respiration rates and ultimately an additional depletion of the C pool (Juo and Lal, 1979; Agboola, 1981; Ellert and Gregorich, 1996; Reicosky et al., 1997; Bruce et al., 1999).

In agricultural areas, the root zone (soil depth affected by plant roots) remains constant over time and is relatively shallow. Different rooting patterns have direct effects on the $\mathrm{C}$ flux, since they affect soil porosity and soil aeration (Berger et al., 2002). Therefore, changes in land use resulting in a modified rooting depth often have a direct influence on soil respiration and $\mathrm{C}$ mineralization rates, and thus on soil turnover (Howard and Howard, 1993).

Ecological restoration is the process of assisting the recovery of an ecosystem that has been degraded, damaged or destroyed as a consequence of human activities (Young et al., 2005), and typically involves a land use change. During the restoration, environmental conditions (e.g., type of vegetation, ecosystem corridors or soil practices) are manipulated to create ecological conditions suitable for the successful establishment of a target composition of species (Prober et al., 2005). The change from agricultural soil to the original forest is a typical example of soil restoration, where natural soil prop- 
erties and vegetation are amended, resulting in an improvement of soil fertility and an ecosystem close to its former natural condition.

\subsection{Modelling of soil $\mathrm{C}$ and $\mathrm{N}$ cycles}

Numerical tools are becoming increasingly used to understand the modifications induced in ecosystems as a result of changes in land use, and it has been found that understanding the coupled $\mathrm{N}$ and $\mathrm{C}$ dynamics is of primary importance for predictive models of SOM evolution, for example to changes in land use and responses to global changes (Rodriguez-Iturbe et al., 2001). Modelling of soil biogeochemical processes dates back to the 1930s (Manzoni and Porporato, 2009), and nowadays an extended list of stochastic, empirical and mechanistic models incorporating soil nutrient dynamics is available. Models vary significantly in terms of complexity and mathematical description of the biological and geochemical processes involved. Manzoni and Porporato (2009) reviewed and classified about 250 different mathematical models developed over $80 \mathrm{y}$. Most of the models currently available evolved from early efforts to provide a concise mathematical description of the soil cycles, and have been adapted and improved to specific applications. The aims of the different models are numerous and include, for example: understanding and prediction of feedbacks between terrestrial ecosystems and global climate (e.g., estimate and predict climatological and biological effects of human activities) (Agren et al., 1991; Melillo, 1996; Moore et al., 2005); influence of climate changes on nutrient cycling in soils (Pastor and Post, 1986; Hunt et al., 1991; Moorhead et al., 1999; Eckersten et al., 2001; Ito, 2007); prediction of changes in soil $\mathrm{C}$ and $\mathrm{N}$ cycles related to possible land use changes (Eckersten and Beier, 1998; Paul and Polglase, 2004; Christiansen et al., 2006; Findeling et al., 2007; Pansu et al., 2007; Post et al., 2007; Kaonga and Coleman, 2008); and forecasts of crop productivity and system response under specific physical soil changes (Wolf et al., 1989; Wolf and Van Keulen, 1989; Matus and Rodríguez, 1994; Parton and Rassmussen, 1994; Henriksen and Breland, 1999; Nicolardot et al., 2001). 
The aim of this manuscript is to provide an overview of the main processes, mechanisms and parameters affecting the evolution of selected soil nutrient cycles (soil $\mathrm{C}$ and $\mathrm{N}$ ) and to provide a modelling framework that incorporates the key mechanisms. Both physical and biological processes, including degradation of litter and humus, and soil moisture evolution on diurnal and seasonal time scales are considered. In the first part of the manuscript, soil $\mathrm{C}$ and $\mathrm{N}$ cycles are summarized, followed by an overview of the most popular models dealing with soil nutrient turnover. In the second part, a compartment model based on Porporato et al. (2003) is described and applied to simulate soil C and N dynamics, as well as degradation and transformation processes occurring under different precipitation and soil scenarios. Contrasting soil types and precipitation regimes are considered, to illustrate modelling capabilities and to show how numerical tools can be used to understand effects of land use changes over soil $\mathrm{C}$ and $\mathrm{N}$ fluxes and, thus, the feasibility and viability of ecological restoration regarding the modelled ecosystem and surroundings.

\section{$2 \mathrm{C}$ and $\mathrm{N}$ cycles in soil}

The global $\mathrm{C}$ cycle can be depicted as consisting of a series of interconnected compartments (terrestrial, aquatic and atmospheric) where $\mathrm{C}$ is stored and transformed. Soils are part of the terrestrial $\mathrm{C}$ pool (Figure 1). The amount of $\mathrm{C}$ stored in the (living and dead) organic matter in soils is three to four times higher than that in the atmosphere (Bruce et al., 1999). The circulation rates are also high. For these reasons, soil $\mathrm{C}$ turnover is of primary importance to developing understanding and forecasting global changes in biogeochemical cycles and climate change (Stevenson and Cole, 1999; RodriguezIturbe and Porporato, 2004). The total global emission of $\mathrm{CO}_{2}$ from soils is probably the largest flux in the global $\mathrm{C}$ cycle, and small changes in the magnitude of soil respiration, if they take place at large scale, could have a tremendous effect on the concentration of $\mathrm{CO}_{2}$ in the atmosphere (Schlesinger and Andrews, 2000; Murty et al., 2002). By the same argument, soils have also a great potential for longterm $\mathrm{C}$ storage. Whether a soil will act as a sink or source of $\mathrm{CO}_{2}$ depends on a number of environ- 
mental factors, including climatic variability and anthropogenic changes in land use, which for example may result in a modified composition of the vegetation and therefore of the quality and quantity of litter inputs (Gignoux et al., 2001).

The principal $\mathrm{C}$ exchange processes between soil and atmosphere are photosynthesis and respiration. Photosynthetic $\mathrm{C}$ fixation by plants - often named primary producers - converts atmospheric $\mathrm{CO}_{2}$ and is the main source of soil organic $\mathrm{C}$. Briefly, during photosynthesis $\mathrm{CO}_{2}$ is used as a $\mathrm{C}$ source to produce complex organic molecules, using sunlight as an energy source (e.g., Killham and Foster, 1994):

$$
\mathrm{CO}_{2}+\mathrm{H}_{2} \mathrm{O}+\text { Energy } \rightarrow \mathrm{CH}_{2} \mathrm{O}+\mathrm{O}_{2} \text {. }
$$

The complex organic molecules produced by plants enter the soil $\mathrm{C}$ cycle as decaying organic matter (litter) and are progressively converted to simpler molecules. A significant fraction of the organic C introduced in the soil is directly used as an energy source to sustain pedofauna metabolism, and is released again to the atmosphere in form of $\mathrm{CO}_{2}$ through respiration:

$$
\mathrm{CH}_{2} \mathrm{O}+\mathrm{O}_{2} \rightarrow \mathrm{CO}_{2}+\mathrm{H}_{2} \mathrm{O}+\text { Energy. }
$$

Another part of the soil $\mathrm{C}$ is assimilated by vegetation and finally transferred to the soil as plant litter, becoming part of SOM (Porporato et al., 2003). Organic C is available in soils in a large variety of forms. Killham and Foster (1994) partitioned the soil organic C into three main pools: insoluble, soluble and biomass. Insoluble soil organic $\mathrm{C}$ includes plant residues and partially decomposed material, which forms the litter and the humus. Soluble $\mathrm{C}$ is a fraction of the humus further decomposed and is rapidly assimilated as a substrate by the pedofauna. The fast consumption of soluble $\mathrm{C}$ explains its often low concentration in the soil (1\%) in comparison to insoluble organic C (90\%). Soil biomass (9\%) consists of microbes and animals (e.g., macroinvertebrates), the decomposition activity of which is mostly responsible for the $\mathrm{C}$ decomposition and recycling (Killham and Foster, 1994). 
Within the soil, organic $\mathrm{C}$ is transferred between the different pools (or compartments) by means of decomposition processes, which are regulated by environmental conditions (e.g., soil moisture) and the $\mathrm{C} / \mathrm{N}$ ratio (Brady and Weil, 2004). These factors will be discussed subsequently. Litter undergoing decomposition is mainly composed of plant residues (fallen leaves, roots, etc.). Decomposition rates are highly variable in time, and are mainly controlled by the environmental conditions (e.g., soil moisture level, aeration, soil temperature) and the quality of the added litter. Complex organic molecules can be decomposed under either aerobic or anaerobic conditions. Under normal conditions, soils are unsaturated and thus $\mathrm{O}_{2}$ is likely to be always available. However, even in the vadose zone saturated conditions can result from, for example, significant precipitation events. Wetlands are a particular case where saturated conditions are found permanently or seasonally. In general, microbial decomposition rates are larger under aerobic conditions (Brady and Weil, 2004), where $\mathrm{O}_{2}$ acts as the electron acceptor during oxidation of organic compounds (Barry et al., 2002). On the other hand, slow decomposition rates under anaerobic conditions can result in accumulation of considerable amounts of partially decomposed organic matter (Figure 2).

Soil $\mathrm{N}$ comes mainly from the atmosphere, which is the largest $\mathrm{N}$ pool and contains almost $75 \%$ of the total $\mathrm{N}$ available on Earth (Barbour et al., 1999). In brief, the soil $\mathrm{N}$ cycle is based upon the uptake of the inorganic forms $\left(\mathrm{NO}_{3}^{-}, \mathrm{NH}_{4}^{+}\right)$by plants. $\mathrm{N}$ returns to the soil in organic form as plant residues, which are decomposed by the soil pedofauna (e.g., invertebrates, microbes, fungi) and are made available to plants in inorganic form.

The total amount of organic $\mathrm{N}$ in soils varies greatly and is influenced by the soil-forming factors likely climate, topography, vegetation, parent material and age. The $\mathrm{N}$ cycle is tightly coupled to the $\mathrm{C}$ cycle, since most of the microbial $\mathrm{N}$ transformations (e.g., nitrification) use energy supplied by $\mathrm{C}$ (Paul, 1976). Although locally $\mathrm{N}$ is also incorporated into soils through dry or wet direct deposition, the largest fraction of soil organic $\mathrm{N}$ fixation is done biologically (conversion from $\mathrm{N}_{2}$ gas to organic 
forms, mediated by specific microbial strains). $\mathrm{N}$ is found in soils mainly within the organic matter fraction, for example humic compounds, plant roots, microbial biomass and decomposing organic materials. The amount of organic $\mathrm{N}$ contained in soils far exceeds that which is present in plantavailable inorganic forms.

The soil $\mathrm{N}$, mainly present in organic form as previously mentioned, is almost unavailable for plants. The vegetation mainly uses inorganic forms of $\mathrm{N}$, which are made available by the SOM decomposition. Soil microorganisms convert the $\mathrm{N}$ contained in the organic matter to $\mathrm{NH}_{4}^{+}$in a process named mineralization (Schinner et al., 1995), further subdivided into two processes. The organic $\mathrm{N}$ is initially transformed via ammonification, and - if $\mathrm{O}_{2}$ is available $-\mathrm{NH}_{4}^{+}$is subsequently oxidized to nitrite $\left(\mathrm{NO}_{2}^{-}\right)$and $\mathrm{NO}_{3}^{-}$, through nitrification:

$$
\begin{gathered}
\mathrm{NH}_{4}^{+}+\mathrm{O}_{2}+\mathrm{H}^{+}+2 \mathrm{e}^{-} \rightarrow \mathrm{NH}_{2} \mathrm{OH}+\mathrm{H}_{2} \mathrm{O} \rightarrow \mathrm{NO}_{2}^{-}+5 \mathrm{H}^{+}+4 \mathrm{e}^{-}, \\
\mathrm{NO}_{2}^{-}+\mathrm{H}_{2} \mathrm{O} \rightarrow \mathrm{NO}_{3}^{-}+2 \mathrm{H}^{+}+2 \mathrm{e}^{-}
\end{gathered}
$$

Although plants can use both forms of inorganic $\mathrm{N}, \mathrm{NO}_{3}^{-}$is used in preference to $\mathrm{NH}_{4}^{+}$because of its greater solubility in water. In other words, nitrates quickly dissolve in the pore solution, which is taken up by plants. On the other hand, however, this also means that $\mathrm{NO}_{3}^{-}$is easily flushed to groundwater. $\mathrm{NH}_{4}^{+}$is instead less mobile because it is strongly adsorbed on clay minerals due to its positive charge.

Denitrification is the anaerobic microbial reduction of $\mathrm{N}$, and $\mathrm{NO}_{3}^{-}$is used as an electron acceptor (i.e., source of energy), resulting in a transfer of soil $\mathrm{N}$ to the atmosphere (Groffman et al., 2002):

$$
2 \mathrm{NO}_{3}^{-}+10 \mathrm{e}^{-}+12 \mathrm{H}^{+} \rightarrow \mathrm{N}_{2}(\mathrm{~g})+6 \mathrm{H}_{2} \mathrm{O} \text {. }
$$

Immobilisation is a process involving microbial uptake of nutrients, where inorganic $\mathrm{N}$ is converted into organic form, such as amino acids and biological macro-molecules. 
The carbon-to-nitrogen ratio $(\mathrm{C} / \mathrm{N})$ is an important factor affecting the overall turnover rates of SOM (Young and Young, 2001). Bacterial sensitivity to the $\mathrm{C} / \mathrm{N}$ ratio is due to the fact that bacteria need a constant $\mathrm{C} / \mathrm{N}$ ratio, while this ratio is highly variable in substrate. For example, intense competition among microorganisms for available $\mathrm{N}$ occurs when soil residues have a high $\mathrm{C} / \mathrm{N}$ ratio, i.e., the substrate is poor in $\mathrm{N}$ making it the limiting factor (Brady and Weil, 2004). Environmental conditions (e.g., soil moisture and temperature) have a direct influence on bacterial activity and thus on this ratio (Koch et al., 2007). The C/N ratio of the substrate tends to decrease as the SOM becomes more decomposed - from fresh litter to highly transformed humus - when microbes are solely responsible for decomposition (Zheng et al., 1999) because the microbial $\mathrm{C} / \mathrm{N}$ ratio is lower than that of litter (Persson, 1983). In other words, the humus is enriched in $\mathrm{N}$ compared to the litter. For this reason the $\mathrm{C} / \mathrm{N}$ ratio of the litter pool controls the rates of mineralization/immobilisation. Young and Young (2001) identified a threshold of the $\mathrm{C} / \mathrm{N}$ ratio which determines the bacterial activity. When $\mathrm{C} / \mathrm{N}>25$, microbes respire completely using the available $\mathrm{C}$ and thus assimilate the entire $\mathrm{N}$ mineralized, and consequently $\mathrm{N}$ is immobilised. In contrast, if $\mathrm{C} / \mathrm{N}<25$, the SOM $\mathrm{N}$ content far exceeds the immobilisation capacity of microbial populations and the result is a net mineralization. Although this threshold seems to be directly related to the $\mathrm{C} / \mathrm{N}$ ratio needs of bacteria, White (1997) argued that this threshold value is variable among different ecosystems, for example because the $\mathrm{C} / \mathrm{N}$ ratio of the vegetation changes depending on the composition and relative frequency of each species. For example, pines produce litter with $\mathrm{C} / \mathrm{N}$ ratio as high as 90 , while litter originating from cereal crops has $\mathrm{C} / \mathrm{N}$ ratio of 80 and tropical forest trees produce litter with $\mathrm{C} / \mathrm{N}$ ratios around 30 (Young and Young, 2001).

\section{Moisture dynamics as a controlling factor of soil carbon and nitrogen cycles}

Soil moisture results from the interactions between climate, soil type (texture, granulometry, organic matter content) and vegetation, and it is consequently variable both in space and time. Among the 
possible physical processes the dynamics of soil moisture exerts the greatest influence over SOM turnover, mineralization, decomposition, leaching and uptake, and its effects are complex and nonlinear. As an example to illustrate this complexity, the production of plant residues - the main source of litter and therefore of energy for the pedofauna - depends on the growth rate of vegetation, which is controlled by water availability. Accumulation of SOM can increase the water retention capacity of the soil, with a positive feed-back on the vegetation. Moreover, the soil biota activity depends on the soil water content, and optimal decomposition rates are only achieved within a relatively narrow soil moisture range.

Soil biota is sensitive to moisture level for several reasons. In order to preserve cell integrity, when the soil water content decreases bacteria increase the intracellular solute concentration to compensate for the extracellular concentration and counterbalance the increased osmotic pressure (Stark and Firestone, 1995; Bell et al., 2008). Therefore, a high concentration of solutes results in an inhibition of the enzymatic activity and therefore decreased cellular activity. Additionally, as the soil becomes drier, water in soil pores becomes a thin layer covering soil grains and substrate availability becomes diffusion-limited. In consequence, microbial activity is further reduced (Csonka, 1989; Stark and Firestone, 1995; Fenchel et al., 1998).

It is however difficult to identify a unique threshold moisture level under which soil respiration (or microbial activity) diminishes. Davidson et al. (1998) and Rey et al. (2002) estimated that $75 \%$ of the soil field capacity corresponds to the soil moisture level below which soil respiration decreases, while according to $\mathrm{Xu}$ et al. (2004) a more likely value is $42 \%$.

A number of studies have shown that soil moisture effects on soil $\mathrm{C}$ and $\mathrm{N}$ turnover also depend on the time-scale of interest. Curiel Yuste et al. (2007) found that, at the seasonal scale, the effect of temperature and soil moisture on $\mathrm{CO}_{2}$ efflux (e.g., soil respiration) was very similar for ponderosa pine and oak savannah ecosystems. For shorter time scales (e.g., daily), decomposition of organic 
matter was mainly controlled by temperature during wet periods and a combination of temperature and soil moisture during dry periods. Soil bacterial growth (or soil respiration) - a parameter often used as a measure of microbial activity - shows a maximum at about $30^{\circ} \mathrm{C}$ (Pietikåinen et al., 2005). Nevertheless, the influence of temperature on microbial activity is generally considered much less important than soil moisture (Rodriguez-Iturbe and Porporato, 2004) because, although important differences in soil temperature are likely to occur at a daily and seasonal scale in the uppermost soil (e.g., first few centimetres), yearly average values at depth are much more constant than those of soil moisture.

Typically, summer drought decreases substantially decomposition rates (Curiel Yuste et al., 2007), but it has been observed that sporadic rains during these dry periods tends to increase the decomposition efficiency of the bacterial communities (Borken et al., 1999; Savage and Davidson, 2001; Borken et al., 2002; Goulden et al., 2004; Xu et al., 2004; Misson et al., 2005; Scott-Denton et al., 2006). Kieft et al. (1998) and Moore et al. (2008) observed an increase of root density and soil microbial activity rate in response to isolated moisture pulses in arid soils, although the response of root density occurred at longer time-scale. A fast rewetting of the soil profile is likely to have negative consequences on microbial populations in that it can generate an osmotic shock and result in cell lyses (Kieft et al., 1987; Van Gestel et al., 1993). In contrast, Ryel et al. (2004), Schwinning and Sala (2004) and Bell et al. (2008) found that, in arid soils, while plants usually do not take advantage of brief pulses of moisture generated by short precipitation events, microbial mineralization is stimulated. Consequently, short-term increases in soil microbial activity triggered by moisture pulses will not typically correlate with an increase in primary production at the same time scale, confirming that plant growth is not only dependent on soil microbial activity, but also on other factors such as the precipitation event duration, amount of soil water infiltrated and the overall change in soil moisture. The magnitude and timing of intra-seasonal precipitation becomes therefore a key regulator for microbial activity (Bell et al., 2008). Since decomposition and consequent mineralization can be stimulated by 
moisture pulses that are too brief to benefit primary producers (e.g., plants) (Cui and Caldwell, 1997; Schwinning et al., 2003; Austin et al., 2004), in arid soils there is potential for soil nutrient pools to accumulate over time and become available to plants as heavier precipitation occurs. The influence of soil moisture over soil nutrient dynamics has been also studied in temperate (Davidson et al., 1998; Buchmann, 2000; Reichstein et al., 2003) and tropical forests (Conant et al., 2000; Davidson et al., 2000; Kiese and Butterbach-Bahl, 2002; Epron et al., 2004). It was concluded that a strong influence of the soil moisture over microbial activity exists, but that the degree of correlation varies strongly among different ecosystems (Buchmann, 2000; Rustad et al., 2000).

\section{Existing models of soil carbon and nitrogen turnover}

At least 250 models dealing with soil $\mathrm{C}$ and nutrient turnover exist (Manzoni and Porporato, 2009). Classification of all these simulators is difficult because they are based on a wide range of physical and biogeochemical descriptions of the processes and the underlying assumptions vary significantly. Nevertheless, based on their internal structure models describing SOM dynamics can be divided into (1) process-oriented, (multi)-compartment models, (2) organism-oriented (food-web) models, (3) cohort models describing decomposition as a continuum, and (4) a combination of model types (1) and (2) (Brussaard, 1998; Smith et al., 1998; Post et al., 2007). Process-oriented or compartment models (each compartment or pool is a fraction of SOM with similar chemical and physical characteristics) are built considering the processes involved in the migration of SOM across the soil profile and its transformations (Smith et al., 1998). Models belonging to this class can potentially have a variable degree of complexity, from the simplest case with no compartments (considering degradation as a continuum) to more refined, multi-compartment models, with each compartment composed of organic matter with similar chemical composition or degradability. Process-oriented models can be combined with GIS software, giving a modelling platform well suited for regional-scale studies. Examples of successful coupling between soil turnover and GIS software are CANDY (Franko, 1996), CENTURY 
(Schimel et al., 1994) and RothC (Post et al., 1982; Jenkinson et al., 1991). On the other hand, the theoretical compartments that define the structure of multi-compartment process-oriented models are difficult to compare with the measurements of SOM fractions, and therefore the testing and validation is difficult and limited (Christensen, 1996; Elliott et al., 1996). Among the most popular processoriented models are also DAISY (Hansen et al., 1991), NCSOIL (Molina et al., 1983) and SOILN (Johnsson et al., 1987).

In organism-based models the SOM flows from one organism pool to another, which in turn are classified depending upon their taxonomy or metabolism. The main advantage of organism-oriented models is that the main drivers of SOM fluxes and transformations - the pedofauna - are explicitly accounted for. However, as noted in Post et al. (2007), to date there is no general acceptance of the existence of a relation between soil biota abundance and degradation rates. In contrast, the relationship between degradation rate and amount (or concentration) of substrate, as in process-based models, is well recognized. Simple first-order kinetic rates are often suitable to model the transformations, and the reaction rates can be easily estimated from laboratory experiments and directly used in processoriented models. Site-specific calibration of organism-oriented models involves the characterization of the soil microbial consortia and therefore requires more complex techniques, while processoriented models are less influenced by the features of the microbial communities, and have a larger range of application to different environments. To summarize, process-oriented models are easier to apply and calibrate than organism-oriented, which explains their greater popularity. Nevertheless, organism-oriented models have been proposed by several authors, including Moore et al. (2004), Kuijper et al. (2005), Zelenev et al. (2006) and Cherif and Loreau (2009).

A cohort is a set of items sharing some particular characteristic. Cohort models divide SOM into cohorts, which are further divided into different pools (e.g., C, N). Contrary to process-based models where decay is usually treated as a purely physical or biochemical process, e.g., described by a first- 
order rate, cohort models consider explicitly microbial physiology as the driving factor of decomposition. An example of a cohort model was proposed by Furniss et al. (1982), where SOM was divided into three cohorts considering age, origin and size, with each cohort subdivided into a number of chemical constituents. Gignoux et al. (2001) developed SOMKO (Soil Organic Matter COhort), where SOM is divided into different cohorts in a demographic sense, meaning that a cohort is a set of items of the same age. At each time step a new cohort is defined and its fate is followed until its relative amount to total SOM becomes negligible. Other examples of models belonging to this class are those of Pastor and Post (1986), Bosatta and Ågren (1991; 1994) and Frolking et al. (2001).

The last group of models consists of a combination of process- and organism-oriented models, which are seldom used because their applicability is limited by the data required to define the organismoriented components (Smith et al., 1998). Some examples of combined models are proposed by O’Brien (1984) and Pausian et al. (1990).

In order to identify to what extent different models are suitable for long-term predictions of soil turnover, and to understand whether some simulators are more suited to specific environmental conditions or ecosystems, model comparisons were conducted using long-term experiments and multi-annual datasets. De Willigen (1991) tested 14 different models comparing their ability to simulate soil N turnover (e.g., mineralization and plant uptake). It was concluded that aboveground processes (e.g., plant growth) were easier to simulate than belowground transformations (e.g., soil water and $\mathrm{N}$ content), and that the more complex, multi-compartment models do not necessarily provide better results in terms of predictive capabilities. Rodrigo et al. (1997) compared the effects of soil moisture and temperature variations on nine different models (NCSOIL; SOILN; DAISY; Kersebaum's model, Kersebaum and Richter, 1991; MATHILD, Lafolie, 1991; TRITSIM, Mirschel et al., 1991; NLEAP, Shaffer et al., 1991; SUNDIAL, Bradbury et al., 1993; CANTIS, Neel, 1996) on predictions of soil C and $\mathrm{N}$ turnover. Not surprisingly, they observed the highest $\mathrm{C}$ decomposition and $\mathrm{N}$ mineralisation 
rates close to field capacity conditions and decreasing rates during soil drying. In this study good agreement between the different models for low moisture conditions was observed, whereas poor agreement was found in wet soils, with water saturation equal or above field capacity. A complete comparison of nine process-oriented multi-compartment models (CANDY; NCSOIL; RothC; DAISY; CENTURY, Parton et al., 1987; Verberne model, Verberne et al., 1990; ITE, Thornley, 1991; DNDC, Li et al., 1994; SOMM, Chertov and Komarov, 1997) was presented by Smith et al. (1997). A qualitative and quantitative evaluation of the performance of the models was carried out by comparing their ability to simulate observed data from seven different sites in temperate regions. A general conclusion of all these comparisons was that the errors derived from the tested models are not significantly different, meaning that the models provide consistent results except when a model is used for an application for which it was not developed. For example, the ITE and SOMM models were developed for grasslands while in the study of Smith et al. (1997) they were applied to crops. Model calibration is an additional source of uncertainties and makes the comparison of different models difficult. Pansu et al. (2004) presented a qualitative comparison of the predictive performance of a family of five multicompartment models, MOMOS-2 to -6 , using ${ }^{14} \mathrm{C}$ - and ${ }^{15} \mathrm{~N}$-labelled species in field experiments. These models use the same conceptual approach but have different complexity, in that the number of compartments varies from 3 to 5 and the description of the biochemical transformation uses a different level of detail and simplification. Pansu et al. (2004) concluded that the simplifications do not decrease significantly model accuracy, but that the use of additional compartments results in improved long-term predictions.

Most of the currently available models are updated versions of earlier and original versions that have been modified to extend the applicability to specific ecosystems. Table 1 presents a list of the five most popular models, their main features together with the key references. The popular CENTURY model, originally devised for modelling soil nutrient dynamics in grassland systems, has been considerably modified since its first version. Smith et al. (1997) and Parton and Rassmussen (1994) modi- 
fied the CENTURY model for application to crop and pasture systems, while Kelly et al. (1997), Peng et al. (1998) and Kirschbaum and Paul (2002) modified the model to be applied to forest ecosystems. Despite the ad hoc modifications, contrasting results in terms of predictive capabilities were obtained. The RothC model of Jenkinson et al. (1990), is an evolution of the model previously presented by Jenkinson and Rayner (1977), named Rothamsted. TOUGHREACT-N (Maggi et al., 2008) was developed to study the biogeochemical soil $\mathrm{N}$ cycle under different conditions of fertilization and irrigation. It is based on the multi-phase, multi-component reactive transport model TOUGHREACT (Xu et al., 2006), in turn an evolved and improved version of TOUGH2 (Pruess et al., 1999). SWIM (Krysanova et al., 1998), based on previously developed tools (MATSALU, Krysanova et al., 1989; SWAT, Arnold et al., 1993) and originally devised for modelling soil N cycle in mesoscale watersheds $\left(10^{2}\right.$ to $\left.10^{4} \mathrm{~km}^{2}\right)$, has recently been extended to better describe groundwater dynamics and processes in riparian zones (Hattermann et al., 2004; Wattenbach et al., 2005). FullCAM (Richards, 2001) accounts for full $\mathrm{C}$ turnover in forests, and is an integrated suite of sub-models: the empirical $\mathrm{C}$ tracking model CAMFor (Richards and Evans, 2000), the tree growth model 3PG (Landsberg and Waring, 1997), the litter decomposition model GENDEC (Moorhead and Reynolds, 1991) and the soil C turnover model RothC (Jenkinson, 1990). PASTIS (Lafolie, 1991; Garnier et al., 2001; Garnier et al., 2003) is a one-dimensional mechanistic model that simulates the transport of water, solutes and heat using Richards' equation for water flow, the advection-dispersion equation for solute transport and the diffusion equation for heat flow. Some variations to this model have been implemented, such as PASTIS $_{\text {mulch }}$ (Findeling et al., (2007), which extends the original capabilities by including the physical effects of a surface residue mulch on rain interception and evaporation. Another example of model evolution is the family of models MOMOS-2 to -6 , which are modified versions from the initial MOMOS-C (Sallih and Pansu, 1993) and MOMOS-N (Pansu et al., 1998) models. TRIPLEX (Peng et al., 2002) is a model of forest growth and $\mathrm{C}$ and $\mathrm{N}$ dynamics, and is a combination of three prior wellestablished models: 3PG (Landsberg and Waring, 1997), TREEDYN3.0 (Bossel, 1996) and CENTU- 
RY4.0 (Parton et al., 1993). Easter et al. (2007) developed a soil C modelling system, GEFSOC, aimed at modelling soil $\mathrm{C}$ stocks and exchange rates at regional or country scales in response to land use changes. The developed tool is based on three well-recognized models: the CENTURY general ecosystem model, the RothC soil C decomposition model and the empirical IPCC method (IPCC, 2003) for assessing soil C stock changes at regional scales. The model can be coupled to a soil and terrain digital database to include the topography and spatial soil variability of the studied area.

\section{Description of the $\mathrm{C}-\mathrm{N}$ model}

The model we describe and use in this work was presented by Porporato et al. (2003). It belongs to the group of process-based models, with the soil organic matter and nutrients divided into five pools. Three pools consist of SOM (litter, humus and microbial biomass), while the remainder are for inorganic N. The model is applied to the root zone treated as a single unit, i.e., spatial variations are ignored.

The framework with three organic pools is in good agreement with Jenkinson (1990), who proposed that process-based models should have between two and four pools to obtain reliable results. These pools represent the main components of the system, and $\mathrm{C}$ and $\mathrm{N}$ concentrations correspond to average values over the rooting depth $\left(Z_{r}\right)$ (Rodriguez-Iturbe and Porporato, 2004). This simplification is justified because soils have often a uniform distribution of SOM and inorganic $\mathrm{N}$ over the whole rooting depth (Porporato et al., 2003). This is not true however for the uppermost soil layer, where organic residues tend to accumulate, and acts as a source of litter to the layers beneath.

Additionally, some other simplifications were made during the development. First, SOM decomposition rates are known to vary over orders of magnitude among the different components and, as already described, each functional group of organisms has specific and highly variable decomposition and mineralization rates. In the model however no distinction is made between different microbial popula- 
tions. Rather, for each pool, a single, first-order kinetic rate is used, which represents an average transformation rate. This approach, although approximate, reduces the number of model parameters and therefore simplifies its calibration. Decomposition rates vary however among the different pools: litter has faster decomposition than the humus pool. The second approximation concerns the $\mathrm{C} / \mathrm{N}$ ratio. As for the transformation rates, the model considers a single $\mathrm{C} / \mathrm{N}$ ratio for each pool, again representing an average value. In this case, the litter $\mathrm{C} / \mathrm{N}$ ratio can be computed, for example, as the weighted average of the $\mathrm{C} / \mathrm{N}$ ratios of the different species, weighted by their relative amount in the ecosystem. Other than this, vegetation characteristics (maximum evapotranspiration, wilting point, incipient stress point, etc.) are assumed constant. This is an important simplification, since in previous sections it was pointed out that climatic conditions influence vegetation growth and deposition of fresh organic matter. The advantage is that we reduce and simplify the external factors influencing $\mathrm{C}$ and $\mathrm{N}$ turnover to soil type and moisture content dynamics.

Model inputs are precipitation and litter fall rates, while on output the extent of soil respiration, plant uptake, transpiration and leaching are recovered. The amount and frequency of precipitation are the only climatic variables considered. Isothermal conditions are assumed, meaning that variations of the average daily temperature within the year are limited. This assumption is clearly not satisfied in many climatic regions (e.g., at high latitude). On the other hand, the model can still be applicable given that, during the unfavourable season (too high or low temperature), the moisture content becomes an additional limiting factor, thus inhibiting soil respiration and transformations.

The model of Porporato et al. (2003) is comprised of a set of coupled non-linear ordinary differential equations. Each equation describes the mass balance of $\mathrm{C}$ and $\mathrm{N}$ in the five pools. An overview of the reaction network is given in Figure 3. Moreover, since the soil moisture is the key factor in this model, and influences the decomposition and turnover rates as outlined above, soil water variations are computed from the water balance at one point. In order to facilitate model understanding and compar- 
ison with previous works, here we use the same notation as in Porporato et al. (2003), D'Odorico et al. (2004) and Rodriguez-Iturbe and Porporato (2004).

The evolution of $\mathrm{C}$ in the litter, humus and biomass pools is given by:

$\frac{d C_{l}}{d t}=A D D+B D-D E C_{l}$

$\frac{d C_{h}}{d t}=r_{h} D E C_{l}-D E C_{h}$

$\frac{d C_{b}}{d t}=\left(1-r_{h}-r_{r}\right) D E C_{l}+\left(1-r_{r}\right) D E C_{h}-B D$,

where $C_{l}, C_{h}$ and $C_{b}$ are the $\mathrm{C}$ concentrations in the litter, humus and biomass pools respectively [M $\left.\mathrm{L}^{-3}\right], A D D$ is the external input of $\mathrm{C}$ to the system $\left[\mathrm{M} \mathrm{L}^{-2} \mathrm{~T}^{-1}\right], B D$ is the recycling rate of decaying biomass in the litter pool $\left[\mathrm{M} \mathrm{L}^{-3} \mathrm{~T}^{-1}\right], D E C_{l}$ and $D E C_{h}$ are the $\mathrm{C}$ fluxes leaving the litter and humus pools due to microbial decomposition $\left[\mathrm{M} \mathrm{L}^{-3} \mathrm{~T}^{-1}\right.$ ], while $r_{h}$ and $r_{r}$ are non-dimensional coefficients representing the fractions of decomposed organic $\mathrm{C}$ that go into the humus pool and to respiration, respectively.

The combination of Eqs. (6) - (8) gives the overall C balance equation $\left(C_{t o t}\right)$ in the system:

$\frac{d C_{t o t}}{d t}=A D D-r_{r} D E C_{l}-r_{r} D E C_{h}$

The flux of $\mathrm{C}$ between two pools is described by first-order kinetic equations $\left(D E C_{l}, D E C_{h}\right.$ and $\left.B D\right)$, where the reaction rates $\left(k_{l}, k_{h}\right.$ and $k_{d}$, respectively) are weighted averages of the decomposition rates of the different organic molecules. The first-order kinetic equations of $\mathrm{C}$ decomposition and microbial death for the litter, humus and biomass pool are:

$$
\begin{aligned}
& D E C_{l}=\varphi f_{d}(s) C_{b} k_{l} C_{l}, \\
& D E C_{h}=\varphi f_{d}(s) C_{b} k_{h} C_{h}, \\
& B D=C_{b} k_{d},
\end{aligned}
$$


where $\varphi$ is a non-dimensional factor that accounts for a possible reduction of the decomposition rate when the litter is very poor in $\mathrm{N}$ (high $\mathrm{C} / \mathrm{N}$ ratio) and the immobilization is not sufficient to integrate the required $\mathrm{N}$ by the bacteria. This factor has an important influence on the dynamics of the biomass evolution, and details on how it is defined and computed can be found in Porporato et al. (2003). The term $f_{d}(s)$ is a non-dimensional parameter that describes soil moisture effects on decomposition:

$f_{d}(s)=\left\{\begin{array}{l}\frac{s}{s_{f c}}, s \leq s_{f c}, \\ \frac{s_{f c}}{s}, s>s_{f c},\end{array}\right.$

where $s_{f c}$ is the soil field capacity (water content held in soil after excess water drained away by gravity). The main model parameters are listed in Table 2.

The $\mathrm{N}$ balance in the litter, humus and biomass pools is computed from the $\mathrm{C}$ balance equations, scaled by the appropriate $\mathrm{C} / \mathrm{N}$ ratio:

$\frac{d N_{l}}{d t}=\frac{A D D}{(C / N)_{a d d}}+\frac{B D}{(C / N)_{b}}-\frac{D E C_{l}}{(C / N)_{l}}$

$\frac{d N_{h}}{d t}=r_{h} \frac{D E C_{l}}{(C / N)_{h}}-\frac{D E C_{h}}{(C / N)_{h}}$

$\frac{d N_{b}}{d t}=\left[1-r_{h} \frac{(C / N)_{l}}{(C / N)_{h}}\right] \frac{D E C_{l}}{(C / N)_{l}}+\frac{D E C_{h}}{(C / N)_{h}}-\frac{B D}{(C / N)_{b}}-\Phi$,

where $N_{l}, N_{h}$ and $N_{b}$ are the $\mathrm{N}$ concentrations in the litter, humus and biomass pools, respectively [M $\left.\mathrm{L}^{-3} \mathrm{~T}^{-1}\right],(C / N)_{a d d},(C / N)_{l},(C / N)_{h}$ and $(C / N)_{b}$ are the $\mathrm{C}$ to $\mathrm{N}$ ratios of added organic matter, litter, humus and biomass pools, respectively, and $\Phi$ is a term that takes into account the contribution due to either the net mineralization or to the immobilization $\left[\mathrm{M} \mathrm{L}^{-3} \mathrm{~T}^{-1}\right]$. This term relates the total mineralization and immobilization rates:

$\Phi=M I N-I M M$, 
where MIN expresses the mineralization rate $\left[\mathrm{M} \mathrm{L}^{-3} \mathrm{~T}^{-1}\right]$ and $I M M$ is the total rate of immobilization (sum of the $\mathrm{N}$ immobilization rate in the $\mathrm{NH}_{4}^{+} I M M^{+}$and $\mathrm{NO}_{3}^{-} I M M^{-}$pools, respectively) $\left[\mathrm{M} \mathrm{L}^{-3} \mathrm{~T}^{-1}\right]$. When $I M M$ is equal to zero, $M I N$ is equal to $\Phi$, while when $M I N$ is zero $I M M$ is equal to $-\Phi$. The $(C / N)_{b}$ ratio is one of the most important parameters in the model, since the switch between mineralization and immobilization is defined in order to maintain as constant the $\mathrm{C} / \mathrm{N}$ ratio of the biomass pool. If the organic matter is rich in $\mathrm{N}$ (and $(C / N)_{b}$ is smaller than the value required to sustain growth of microbial biomass), decomposition results in surplus $\mathrm{N}$. This is used by the microorganisms, and mineralization occurs. In contrast, if decomposition produces an environment poor in N, microorganisms will increase the immobilization rate of $\mathrm{NH}_{4}^{+}$and $\mathrm{NO}_{3}^{-}$in order to meet their requirements. This process is rather complex and very dynamic, as explained in Porporato et al. (2003).

$\mathrm{N}$ transfer between the pools is described by the same first-order kinetic transfer parameters used for $\mathrm{C}$, with each term scaled by the corresponding $\mathrm{C} / \mathrm{N}$ ratio (Figure 3). The balance equations of inorganic $\mathrm{N}$ are:

$\frac{d N^{+}}{d t}=M I N+I M M^{+}-N I T-L E^{+}-U P^{+}$

$\frac{d N^{-}}{d t}=N I T-I M M^{-}-L E^{-}-U P^{-}$,

where $N^{+}$and $N$ are the inorganic $\mathrm{N}$ concentrations in the $\mathrm{NH}_{4}^{+}$and $\mathrm{NO}_{3}^{-}$pools, respectively $\left[\mathrm{M} \mathrm{L}^{-3}\right.$, NIT is the nitrification rate $\left[\mathrm{M} \mathrm{L}^{-3} \mathrm{~T}^{-1}\right], U P^{+}$and $U P^{-}$are the $\mathrm{N}$ uptake by plants from the $\mathrm{NH}_{4}^{+}$and $\mathrm{NO}_{3}^{-}$pools, respectively $\left[\mathrm{M} \mathrm{L}^{-3} \mathrm{~T}^{-1}\right]$, and $L E^{+}$and $L E$ are $\mathrm{N}$ fluxes from the root zone towards the groundwater $\left[\mathrm{M} \mathrm{L}^{-3} \mathrm{~T}^{-1}\right]$.

The combination of Eqs. (14)-(16), (18) and (19) gives the overall evolution of total $\mathrm{N}\left(N_{t o t}\right)$ in the system: 
$\frac{d N_{t o t}}{d t}=\frac{A D D}{(C / N)_{a d d}}-L E^{+}-U P^{+}-L E^{-}-U P^{-}$.

Eqs. (9) and (20) represent the total $\mathrm{C}$ and $\mathrm{N}$ sinks and sources of the system depicted in Figure 3.

Although we have described the main elements of the model here, further descriptions - for example the rates of mineralization $(M I N)$, immobilization $\left(I M M^{+}\right.$and $\left.I M M\right)$, nitrification (NIT), plant uptake $\left(U P^{+}\right.$and $\left.U P^{-}\right)$and leaching $\left(L E^{+}\right.$and $\left.L E\right)$ and their associated variables - can be found in Porporato et al. (2003), D’Odorico et al. (2004) and Rodriguez-Iturbe and Porporato (2004), together with additional discussion about the underlying assumptions and simplifications introduced in this model.

\section{Modelling scenarios}

It has been shown in previous sections that land use change and hydroclimatic conditions are the main factors contributing to changes in soil $\mathrm{C}$ and $\mathrm{N}$ turnover. To test the relevance of mechanisms and parameters contributing to the fate of soil $\mathrm{C}$ and $\mathrm{N}$, different modelling scenarios were simulated, for which the main variables are presented in Table 3. The combination of two different soils and two different climatic conditions gives four different scenarios, the results of which are presented subsequently. Due to the high frequency of $\mathrm{NO}_{3}^{-}$variations and their importance to plant growth, D'Odorico et al. (2003) found that a daily temporal resolution was necessary to capture the impact of soil moisture on nutrient dynamics. A daily time step was used here also. The same initial $\mathrm{C}$ and $\mathrm{N}$ amounts in different pools, as well the same decomposition, mineralization and root uptake rates were considered in all scenarios, thereby allowing for a direct comparison between them. These values, presented in Table 4, were taken from D'Odorico et al. (2003).

\subsection{Climate scenarios}

The occurrence and amount of precipitation are both intermittent and unpredictable. Precipitation scenarios were generated with a stochastic procedure described in Laio et al. (2001). Rainfall was 
assumed to follow a Poisson distribution with frequency $\lambda\left[\mathrm{T}^{-1}\right]$, and each rainfall event had infiltration sampled from an exponential distribution with mean $\alpha[\mathrm{L}]$. Two different climates were considered with a different occurrence of precipitation. Rainfall interception by canopy depends on the vegetation type and structure and cannot be neglected, especially in arid areas where the evaporation rate can be significant. Canopy interception is accounted for in the model by defining a threshold value (e.g., high values for forests and low for grasslands) below which no rainfall reaches the soil surface. If instead the rainfall depth is higher than the threshold value, the total amount of rainfall reaching the soil surface is equal to the rainfall depth reduced by the canopy interception.

Parameters representing the two climates considered are presented in Table 3. Climate $A$ is characterized by seasonality represented by two wet and two dry seasons over a year. This climate can be considered comparable to a Mediterranean climate, with two wet seasons, spring and fall (e.g., high $\lambda$ and $\alpha$ ) and two dry seasons, summer and winter (e.g., low $\lambda$ and $\alpha$ ). In contrast, climate $B$ is characterized by a lack of seasonality, with relatively low but homogeneous amount of precipitation randomly distributed over the year, using $\lambda$ and $\alpha$ between those of the wet and dry seasons considered in climate A.

Although in Section 3 was pointed out that temperature exerts a control over soil C and $\mathrm{N}$ cycles, in this study only isothermal conditions were considered. This assumption was made for two reasons. First, the effect of temperature in many climates is less important than that of soil moisture and, second, because considering the effects of soil moisture alone the number of factors affecting soil nutrient cycles is reduced, and is therefore easier to understand the influence and feedbacks on soil changes and nutrient dynamics. Temperature variations are however closely related to climate conditions and therefore this factor should be considered in future analyses. 


\subsection{Soil scenarios}

We seek to identify whether different patterns of soil moisture evolve through time as a consequence of the combination of different processes in the soil-plant-atmosphere system. To this end, Eq. (21) is used to calculate the soil moisture balance at a point (Laio et al., 2001):

$n Z_{r} \frac{d s(t)}{d t}=R(t)-I(t)-Q[s(t) ; t]-E[s(t)]-L[s(t)]$

where $n$ is the porosity; $Z_{r}$ is the depth of active soil or root depth [L]; $s(t)$ is the relative soil moisture content $(0 \leq s(t) \leq 1) ; R(t)$ is the rainfall rate $\left[\mathrm{L} \mathrm{T}^{-1}\right] ; I(t)$ is the amount of rainfall lost through interception by canopy cover $\left[\mathrm{L} \mathrm{T}^{-1}\right] ; Q[s(t) ; t]$ is the rate of runoff $\left[\mathrm{L} \mathrm{T}^{-1}\right] ; E[s(t)]$ is the evapotranspiration rate $\left[\mathrm{L} \mathrm{T}^{-1}\right]$; and $L[s(t)]$ is the leakage rate $\left[\mathrm{L} \mathrm{T}^{-1}\right]$.

The soil was assumed as a horizontal and homogeneous layer of depth $Z_{r}$. This is an important assumption because soil depth depends in time and space on two main parameters, soil structure and vegetation. In the simulations we considered the same soil depth for water balance and nutrient cycles. Water infiltration into the soil and runoff are entirely controlled by soil moisture dynamics, since water will infiltrate into the soil if there is available storage. Excess rainfall that cannot be stored in the soil is converted into runoff.

Although the vegetation type depends on both climate and soil, here the vegetation parameters were fixed for each soil in order to reduce the number of variables affecting changes in $\mathrm{C}$ and $\mathrm{N}$ fluxes (Table 3). This is also justified by the fact that vegetation parameters mostly depends on soil moisture, which directly depends on soil characteristics. Evapotranspiration varies from a maximum value $E_{\max }$ when soil moisture ranges between the maximum, unity, and the point of incipient stress, $s^{*}$ (soil moisture level at which the plants begin to close stomata in response to water stress). The evapotranspiration rate decreases linearly from $E_{\max }$ to $E_{w}$, the latter rate corresponding to the soil moisture at the wilting point $s_{w}$ (soil water content at which plants wilt and can no longer recover or, in terms of 
water potential, is defined as the suction head beyond which the plant can no longer take up water). Below this value, only transpiration is active, and the water loss rate is linear from $E_{w}$ to zero at the point of hygroscopic water $s_{h}$ (microscopic film of water covering soil particles not available for plants). More details and assumptions concerning evapotranspiration are given by Laio et al. (2001).

Verhoef and Brussaard (1990) defined a series of functional groups of pedofauna based on their contribution to nutrient decomposition and mineralization. Organisms belonging to the same functional group play a similar role in decomposition-mineralization transformations. For example, there is a functional group that includes organisms that pulverize, mix and granulate the soil. Such organisms are rather important because (i) they contribute to incorporate the organic residues available on the surface into the lower horizons, and (ii) they create large pores and channels that guarantee aeration of the soil profile and eliminate excess water. Other functional groups include pedofauna specialized in breaking down woody recalcitrant materials, in degrading litter and digesting organic residues, etc. (Brady and Weil, 2004). Although the functional group concept is useful for modelling of soil nutrient cycles, here a more simplified approach considering a single value for nutrient decomposition and mineralization rates is used, representing the contribution of the entire pedofauna to these processes.

In combination with climates $A$ and $B$, two soil types - named I and II - are considered, representative of agricultural and forest soils respectively (Table 3). Agricultural and forest soils have contrasting physical properties mainly due to management practices and the type of vegetation supported (Lutz and Chandler, 1955; Carmean, 1957; García-Oliva et al., 1994; de Moraes et al., 1996; Islam and Weil, 2000). The main differences between these soils are:

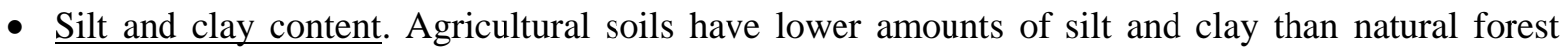
soils, mostly as a result of preferential removal of these particles by water erosion (Islam and Weil, 2000); 
- Soil aggregate stability. A higher input of litter fall combined with the absence of tillage and ploughing practices gives rise to forest soils with greater soil aggregate stability (Islam and Weil, 2000). Furthermore, forest soils are naturally protected from the impact of raindrops by the canopy and organic matter at the soil surface that absorbs raindrop energy (Carmean, 1957). In practice, the effect of raindrops is (i) removal of silt and clay particles and (ii) disruption of soil aggregates that subsequently can block large pores and reduce water percolation;

- Bulk density and porosity. Agricultural soils have higher bulk density and lower porosity than forest soils, mainly because of a greater residual sand content combined with poorer soil aggregation (García-Oliva et al., 1994; de Moraes et al., 1996);

- Soil structure. Agricultural soils often have a deteriorated structure in comparison to forest soils. This deterioration is apparent in pore modification, increased bulk density, increased compaction, and less stable aggregates (Carmean, 1957). In addition, compacted, impermeable layers or pans within the soil profile often develop as a consequence of repeated ploughing, mainly under wheel track patterns (Roger-Estrade et al., 2004; Coquet et al., 2005);

- Infiltration rate. As a consequence of above mentioned properties, which contribute to reduce the average pore size and their connectivity, the rate of infiltration is reduced in agricultural soils. Additionally, forest vegetation has more extensive root networks, leading to large number of interconnected channels leading to rapid water infiltration (Lutz and Chandler, 1955);

- Runoff and soil erosion. Low infiltration rates of agricultural soils contribute to increased runoff, which emphasizes soil erosion and removal of silt-clay soil particles (Lutz and Chandler, 1955).

Due to the above differences, the agricultural soil (soil I) is characterized by a relatively low saturated hydraulic conductivity $(K)$, as well as lower values of pore size distribution $(b)$, porosity $(n)$ and soil field capacity $\left(s_{f c}\right)$ than soil II, representative of a forest soil (Ndiaye et al., 2007). Furthermore, the 
soil tortuosity is likely to be affected by the loss of structure and by the less extended root network of agricultural soils, the loss of connected porosity due to tillage processes and disturbed aggregates clogging large pores. The soil tortuosity index for the agricultural soil is also thus decreased in comparison with the forest soil (Table 3).

The rooting depth $\left(Z_{r}\right)$ considered is larger for forest soils than agricultural soils, since the root network is much more important for forest vegetation than agricultural. As previously mentioned, vegetation depends on both climate and soil. However, we have defined the vegetation parameters only in function of the soil type. As a consequence of the low $\mathrm{C} / \mathrm{N}$ ratio of agricultural vegetation and microbial decomposers associated, cultivated soils typically have lower $\mathrm{C} / \mathrm{N}$ ratio than forest soils (Zheng et al., 1999). Nevertheless, to facilitate the comparison between the four scenarios we assumed equal $\mathrm{C} / \mathrm{N}$ ratios for both soils, as well as initial $\mathrm{C}$ and $\mathrm{N}$ concentrations.

\section{Results}

Figures $4 \mathrm{a}$ and d present the precipitation over $20 \mathrm{y}$ for climates $A$ (seasonality) and $B$ (no seasonality), respectively, while the evolution of water saturation for the same period - as computed with Eq. (21) - for each climate and soil type is depicted in Figures $4 \mathrm{~b}, \mathrm{c}$ and e, f, respectively. There is a marked difference in precipitation distribution between climates $A$ and $B$, with wet and dry seasons in climate $A$ and random uniformly distributed precipitation in climate $B$. Soil water saturation follows the dynamics imposed by precipitation, more notably in agricultural soils while the trend in water saturation evolution is smoothed in forest soils. As expected, peaks of soil saturation are lower for those soils under the influence of climate $B$ than climate $A$, while water saturation in agricultural soils is lower than those of forest soils. The latter is due to different vegetation parameters associated with each soil type, specifically to the wilting point $\left(s_{w}\right)$, fixed at 0.05 and 0.17 for agricultural and forest soils, respectively. It is interesting to note that forest soils attenuate changes of soil saturation much 
more than agricultural soils (e.g., compare Figures $4 \mathrm{~b}$ to $\mathrm{c}$ or even Figures $4 \mathrm{e}$ to $\mathrm{f}$ ), and delays water saturation peaks, mostly due to difference rooting depth.

The evolution of the five different nutrient pools, for agricultural and forest soils under the conditions of climate $A$, are presented in Figure 5. Figures corresponding to the same pool are depicted with the same vertical scale in order to facilitate comparison between them. From the comparison is evident that seasonal effects are much more visible in agricultural than in forest soils. The lower rooting depth $\left(Z_{r}\right)$, soil hydraulic conductivity $(K)$ and soil porosity $(n)$ in the agricultural soil may be at the origin of these differences. Although forest soils present similar behaviour, small peaks observed in agricultural soils and corresponding to high frequency changes in precipitation, are not evident. As previously mentioned, litter decomposition in agricultural soils is enhanced by tillage and plough practices, represented in the model by lower values of saturated hydraulic conductivity $(K)$, pore size distribution $(b)$, porosity $(n)$ and soil field capacity $\left(s_{f c}\right)$. This explains the lower values of $\mathrm{C}$ litter pool in agricultural soils (compare Figures 5a and f), although the high influence of seasonal climates over agricultural soils is likely to hide this fact. Furthermore, this trend is likely to influence the evolution of subsequent pools (Figures 5g-j). Peaks of litter $\mathrm{C}$ match well the biomass pool decrease, while decreases of litter $\mathrm{C}$ concentrations well correlate with the peaks of $\mathrm{C}$ concentration in the biomass pool for both agricultural and forest soils. This is not surprising since the augmentation of the biomass pool is linked to degradation of the litter pool. C concentrations in the humus pool $\left(C_{h}\right)$ for agricultural and forest soils are lower than in other pools, since this pool is an intermediate pool between litter and biomass and there is almost no interaction with other variables. Concentrations of $\mathrm{NH}_{4}^{+}$(Figures $5 \mathrm{~d}$ and i) show a trend similar to that of $\mathrm{C}$ in the litter pool, although $\mathrm{NH}_{4}^{+}$variations are almost negligible since its concentration is very low. The $\mathrm{NO}_{3}^{-}$pool preserves much of the high-frequency variability imposed by the random forcing of precipitation, which is not surprising since $\mathrm{NO}_{3}^{-}$dynamics are the final product of a number of intertwined processes in which both high- and low-frequency components interact. It is interesting to note the low levels of $\mathrm{NO}_{3}^{-}$obtained for agricultural soils (Figure 5e) 
compared with the relatively high levels in forest soils (Figure 5j). This is reflected in Figure $6 \mathrm{~d}$ and $\mathrm{h}$, where $\mathrm{NO}_{3}^{-}$leaching is almost non-existent in forest soils while it is relatively important for agricultural soils. The higher rates of mineralization and $\mathrm{NO}_{3}^{-}$uptake in agricultural soils than in forest soils aid to explain this fact. Note that fertilization practices commonly undertaken in agricultural soils are not considered in the model. Thus, simulated results are in good agreement with the need of agricultural soils for regular fertilizer input, since high decomposition and mineralization rates (Figures $6 \mathrm{a}$ and b), $\mathrm{NO}_{3}^{-}$uptake by plants (Figure 6c) and $\mathrm{NO}_{3}^{-}$leaching (Figure $6 \mathrm{~d}$ ) to lower layers results in low levels of $\mathrm{NO}_{3}^{-}$available for plants.

The results obtained, especially in forest soils, provide evidence of a structure with temporal amplitudes considerably larger than the one induced by the stochastic hydrologic forcing. This behaviour was already observed by Thornley et al. (1995) and D’Odorico et al. (2003). The presence of this behaviour in soil nutrient dynamics (see Figures $5 f-\mathrm{j}$ ), a priori not related to climatic conditions, is a manifestation of the nonlinearity and degree of complexity of the whole system. Thornley et al. (1995) pointed out that such behaviour suggests that soil nutrients cycles could show cases of richer (perhaps chaotic) dynamics enmeshed with the variability that is directly induced by the stochastic hydrologic fluctuations. This issue is not fully assessed yet to date, although a partial discussion is provided by Manzoni and Porporato (2007).

The evolution through time of the $\mathrm{C}$ and $\mathrm{N}$ pools in agricultural and forest soils under climate $B$ (no seasonality) is presented in Figure 7. A general trend for both agricultural and forest soil is that simulated concentrations in all $\mathrm{C}$ and $\mathrm{N}$ pools closely reproduce the concentrations observed in climate $A$ (seasonal). This is supported by the similar decomposition rates between climate $A$ (Figure 6) and $B$ (Figure 8). Nevertheless, the absence of seasonality, which is reflected in agricultural and forest soils by a loss of the high frequency nutrient peaks, is finally translated in less nitrate leaching and less variability in the soil nutrients. While water saturation changes under seasonal climates contribute to 
hinder decomposition rates from time to time, this does not occur in climates without seasonal effects, where decomposition peaks are more continuous through time. The loss of climate seasonality affects neither the inverse trend between litter and biomass pools, nor the high frequency of $\mathrm{NO}_{3}^{-}$changes in both agricultural and forest soils.

As observed under seasonal conditions, the frequency of changes in $\mathrm{C}$ and $\mathrm{N}$ concentrations is higher in agricultural than in forest soils, although the general trend remains quite similar for both soils. Again, $\mathrm{C}$ concentrations in the humus pool are relatively constant, and $\mathrm{NH}_{4}^{+}$concentrations are low. Concentrations of $\mathrm{NO}_{3}^{-}$are lower in agricultural soils than in forest soils, as observed under seasonal climate conditions. This fact supports what was mentioned in previous sections that agricultural soils are relatively poor in nutrients, independently of climate conditions. Furthermore, this is consistent with the higher mineralization rate (Figure $8 \mathrm{~b}$ ), higher $\mathrm{NO}_{3}^{-}$uptake by plants (Figure $8 \mathrm{c}$ ) and higher loss of $\mathrm{NO}_{3}^{-}$by leaching (Figure $8 \mathrm{~d}$ ) in agricultural than in forest soils.

Finally, some general insights can be gained from the model results. Great variations of the average value of $\mathrm{C}$ and $\mathrm{N}$ concentrations in forest soils are obtained both under seasonal and uniformly variable climatic conditions. These results show that a point measurement of litter, for example, is almost meaningless, and that time-series are needed to provide useful information for evaluation of soil nutrient turnover. It is worth noting also that steady state concentrations are not always reached, which means that longer simulations should be applied to better evaluate long term nutrient concentrations, mainly under non-seasonal conditions (see for example Figure $5 \mathrm{~g}$ in comparison to $\mathrm{b}$ ).

\section{Conclusions}

Land use changes affect soil properties and, thus, nutrient cycling dynamics. Changing soil properties means also changing the type of vegetation, altering even more the concomitant nutrient cycles. The example most widely observed is the change from forest to agricultural soils, due to increasing an- 
thropogenic demands for food production. Agricultural practices generally cause changes in soil structure, compromising aggregation and porosity, leading to a soil structure decline. Tillage practices like mechanical mixing compact and reduce the size of aggregates and fills pore spaces with fines. The simulation of two different climates applied to two contrasting soil types (where specific vegetation properties were linked to each soil), showed that decomposition rates in agricultural soils are higher, which in addition to lower input of fresh litter over a year in comparison to a forested area, results in lower $\mathrm{C}$ and $\mathrm{N}$ concentrations. In consequence, less $\mathrm{NO}_{3}^{-}$is available to plants, since plant $\mathrm{NO}_{3}^{-}$uptake is higher and leaching is enhanced under these conditions. The leached $\mathrm{NO}_{3}^{-}$is compensated for by the input of extra nutrients in agricultural soils via fertilization, a practice that, if poorly managed, contributes to diminish the quality of aquifers.

Model application under seasonal and non-seasonal climatic conditions resulted in a higher attenuation of punctual growing concentrations of soil $\mathrm{C}$ and $\mathrm{N}$ under the effect of a seasonal climate, as well as average concentrations higher than those under the effect of non-seasonal climates. Furthermore, the high frequency imposed by seasonal climates is attenuated in forest soils, while this high frequency is reflected in agricultural soil nutrient cycles. Nevertheless, the general trend of the temporal dynamic is similar under both seasonal and non-seasonal conditions.

Land use changes should include long term practices to avoid the loss of soil properties, contributing to the maintenance of optimal conditions for long term agricultural production. Crop rotation is an important management practice to avoid soil $\mathrm{C}$ losses following conversion from forest to agricultural land (Murty et al., 2002). Furthermore, Agboola (1981) and Bruce et al. (1999) proposed that a diminution of tillage processes minimizes soil erosion and decomposition rates, and thus soil C losses. The results presented here underscore that models dealing with soil nutrient turnover are potentially promising tools to design new soil practices and predict long-term effects of these practices on soil fertility. 


\section{Acknowledgements}

This research is part of the RECORD project of the Competence Centre Environment and Sustainability (CCES, http://www.cces.ethz.ch/projects/nature/Record). Funding has been provided by the Swiss National Science Foundation under grant 200021-113296. 


\section{References}

Agboola A.A. (1981) The effects of different soil tillage and management practices on the physical and chemical properties of soil and maize yields in a rainforest zone of Western Nigeria, Agron. J. 73, 247-251.

Agren G.I., R.E. McMurtrie, W.J. Parton, J. Pastor, H.H. Shugart. (1991) State-of-the-art of models of production-decomposition linkages in conifer and grassland ecosystems, Ecol. Appl. 1, 118-138. DOI: $10.2307 / 1941806$.

Arnold J.G., P.M. Allen, G. Bernhardt. (1993) A comprehensive surface-groundwater flow model, J. Hydrol. 142, 47-69. DOI: 10.1016/0022-1694(93)90004-S.

Austin A.T., L. Yahdjian, J.M. Stark, J. Belnap, A. Porporato, U. Norton, D.A. Ravetta, S.M. Schaeffer. (2004) Water pulses and biogeochemical cycles in arid and semiarid ecosystems, Oecologia 141, 221-235. DOI: $10.1007 / \mathrm{s} 00442-004-1519-1$.

Barbour M.G., J.H. Burk, W.D. Pitts, F.S. Gilliam, M.W. Schwartz. (1999) Terrestrial plant ecology. Pearson Benjamin Cummings, Menlo Park (Canada).

Barry D.A., H. Prommer, C.T. Miller, P. Engesgaard, A. Brun, C. Zheng. (2002) Modelling the fate of oxidisable organic contaminants in groundwater, Adv. Water Res. 25, 945-983. DOI: 10.1016/S03091708(02)00044-1.

Bell C., N. McIntyre, S. Cox, D. Tissue, J. Zak. (2008) Soil microbial responses to temporal variations of moisture and temperature in a Chihuahuan desert grassland, Microb. Ecol. 56, 153-167. DOI: $10.1007 / \mathrm{s} 00248-007-9333-\mathrm{z}$.

Berger T.W., C. Neubauer, G. Glatzel. (2002) Factors controlling soil carbon and nitrogen stores in pure stands of Norway spruce (Picea abies) and mixed species stands in Austria, Forest Ecol. Manage. 159, 3-14. DOI: $10.1016 / \mathrm{S} 0378-1127(01) 00705-8$

Bolker B.J., S.W. Pacala, W.J. Parton. (1998) Linear analysis of soil decomposition: insights from the century model, Ecol. Appl. 8, 425-439. DOI: 10.1890/1051-0761(1998)008[0425:LAOSDI]2.0.CO;2.

Bonde T.A., B.T. Christensen, C.C. Cerri. (1992) Dynamics of soil organic matter as reflected by natural ${ }^{13} \mathrm{C}$ abundance in particle size fractions of forested and cultivated oxisols, Soil Biol. Biochem. 24, 275-277. DOI: 10.1016/0038-0717(92)90230-U.

Borken W., Y.-J. Xu, E.A. Davidson, F. Beese. (2002) Site and temporal variation of soil respiration in European beech, Norway spruce, and Scots pine forests, Global Change Biol. 8, 1205-1216. DOI: 10.1046/j.1365-2486.2002.00547.x.

Borken W., Y.J. Xu, R. Brumme, N. Lamersdorf. (1999) A Climate Change Scenario for Carbon Dioxide and Dissolved Organic Carbon Fluxes from a Temperate Forest Soil: Drought and Rewetting Effects, Soil Sci. Soc. Am. J. 63, 1848-1855.

Bosatta E., G.I. Agren. (1991) Theoretical analysis of carbon and nutrient interactions in soils under energylimited conditions, Soil Sci. Soc. Am. J. 55, 728-733.

Bosatta E., G.I. Ågren. (1994) Theoretical analysis of microbial biomass dynamics in soils, Soil Biol. Biochem. 26, 143-148. DOI: 10.1016/0038-0717(94)90206-2.

Bossel H. (1996) TREEDYN3 forest simulation model, Ecol. Modell. 90, 187-227. DOI: 10.1016/03043800(95)00139-5

Bradbury N.J., A.P. Whitmore, P.B.S. Hart, D.S. Jenkinson. (1993) Modelling the fate of nitrogen in crop and soil in the years following application of ${ }^{15} \mathrm{~N}$-labelled fertilizer to winter wheat, J. Agric. Sci. Cambridge 121, 363-379. DOI: 10.1017/S0021859600085567.

Brady N.C., R.R. Weil. (2004) Elements of the nature and properties of soils. Pearson Prentice Hall, Upper Saddle River, New Jersey (US). 
Brams E. (1971) Continuous cultivation of West African soils: Organic matter diminution and effects of applied lime and phosphorus, Plant and Soil 35, 401-414. DOI: 10.1007/BF01372671.

Brown S., A. Lugo. (1990) Effects of forest clearing and succession on the carbon and nitrogen content of soils in Puerto Rico and US Virgin Islands, Plant and Soil 124, 53-64. DOI: 10.1007/BF00010931.

Bruce J.P., M. Frome, E. Haites, H. Janzen, R. Lal, K. Paustian. (1999) Carbon sequestration in soils, J. Soil Water Conserv. 54, 382-389.

Brussaard L. (1998) Soil fauna, guilds, functional groups and ecosystem processes, Appl. Soil Ecol. 9, $123-135$. DOI: $10.1016 /$ S0929-1393(98)00066-3

Buchmann N. (2000) Biotic and abiotic factors controlling soil respiration rates in Picea abies stands, Soil Biol. Biochem. 32, 1625-1635. DOI: 10.1016/S0038-0717(00)00077-8.

Carmean W.H. (1957) The structure of forest soils, Ohio J. Sci. 57, 165-168.

Cherif M., M. Loreau. (2009) When microbes and consumers determine the limiting nutrient of autotrophs: a theoretical analysis, Proc. R. Soc. B 276, 487-497. DOI: 10.1098/rspb.2008.0560.

Chertov O.G., A.S. Komarov. (1997) SOMM: A model of soil organic matter dynamics, Ecol. Modell. 94, $177-$ 189. DOI: $10.1016 / \mathrm{S} 0304-3800(96) 00017-8$

Christensen B.T. (1996) Matching measurable soil organic matter fractions with conceptual pools in simulation models of carbon turnover: revision of model structure, in: D.S. Powlson, P. Smith, J.U. Smith (Eds.), Evaluation of soil organic matter models, Springer Verlag, Berlin, pp. 143-160.

Christiansen J.R., B. Elberling, P.E. Jansson. (2006) Modelling water balance and nitrate leaching in temperate Norway spruce and beech forests located on the same soil type with the CoupModel, Forest Ecol. Manage. 237, 545-556. DOI: 10.1016/j.foreco.2006.09.090

Conant R.T., J.M. Klopatek, C.C. Klopatek. (2000) Environmental factors controlling soil respiration in three semiarid ecosystems, Soil Sci. Soc. Am. J. 64, 383-390.

Coquet Y., J. Simunek, C. Coutadeur, M.T. van Genuchten, V. Pot, J. Roger-Estrade. (2005) Water and solute transport in a cultivated silt loam soil. 2. Numerical analysis, Vadose Zone J. 4, 587-601. DOI: 10.2136/vzj2004.0153.

Csonka L.N. (1989) Physiological and genetic responses of bacteria to osmotic stress, Microbiol. Rev. 53, 121 147. DOI: 0146-0749/89/010121.

Cui M., M.M. Caldwell. (1997) A large ephemeral release of nitrogen upon wetting of dry soil and corresponding root responses in the field, Plant and Soil 191, 291-299. DOI: 10.1023/A:1004290705961.

Curiel Yuste J., D.D. Baldocchi, A. Gershenson, A. Goldstein, L. Misson, S. Wong. (2007) Microbial soil respiration and its dependency on carbon inputs, soil temperature and moisture, Global Change Biol. 13, 2018-2035. DOI: 10.1111/j.1365-2486.2007.01415.x.

D'Odorico P., F. Laio, A. Porporato, I. Rodriguez-Iturbe. (2003) Hydrologic controls on soil carbon and nitrogen cycles. II. A case study, Adv. Water Res. 26, 59-70. DOI: 10.1016/S0309-1708(02)00095-7.

D'Odorico P., A. Porporato, F. Laio, L. Ridolfi, I. Rodriguez-Iturbe. (2004) Probabilistic modeling of nitrogen and carbon dynamics in water-limited ecosystems, Ecol. Modell. 179, 205-219. DOI: 10.1016/j.ecolmodel.2004.06.005.

Dalal R.C., R.J. Mayeer. (1986) Long-term trends in fertility of soils under continuous cultivation and cereal cropping in Southern Queensland. I. Overall changes in soil properties and trends in winter cereal yield, Austr. J. Soil Res. 24, 265-279. DOI: 10.1071/SR9860265.

Davidson E.A., I.L. Ackerman. (1993) Changes in soil carbon inventories following cultivation of previously untilled soils, Biogeochemistry 20, 161-193. DOI: 10.1007/BF00000786. 
Davidson E.A., E. Belk, R.D. Boone. (1998) Soil water content and temperature as independent or confounded factors controlling soil respiration in a temperate mixed hardwood forest, Global Change Biol. 4, 217 227. DOI: 10.1046/j.1365-2486.1998.00128.x.

Davidson E.A., L.V. Verchot, J.H. Cattânio, I.L. Ackerman, J.E.M. Carvalho. (2000) Effects of soil water content on soil respiration in forests and cattle pastures of eastern Amazonia, Biogeochemistry 48, 53-69. DOI: 10.1023/A:1006204113917.

de Moraes J.F.L., B. Volkoff, C.C. Cerri, M. Bernoux. (1996) Soil properties under Amazon forest and changes due to pasture installation in Rondônia, Brazil, Geoderma 70, 63-81. DOI: 10.1016/00167061(95)00072-0.

de Willigen P. (1991) Nitrogen turnover in the soil-crop system; comparison of fourteen simulation models, Nutr. Cycling Agroecosyst. 27, 141-149. DOI: 10.1007/BF01051122.

Desjardins T., F. Andreux, B. Volkoff, C.C. Cerri. (1994) Organic carbon and ${ }^{13} \mathrm{C}$ contents in soils and soil sizefractions, and their changes due to deforestation and pasture installation in eastern Amazonia, Geoderma 61, 103-118. DOI: 10.1016/0016-7061(94)90013-2

Easter M., K. Paustian, K. Killian, S. Williams, T. Feng, R. Al-Adamat, N.H. Batjes, M. Bernoux, T. Bhattacharyya, C.C. Cerri, C.E.P. Cerri, K. Coleman, P. Falloon, C. Feller, P. Gicheru, P. Kamoni, E. Milne, D.K. Pal, D.S. Powlson, Z. Rawajfih, M. Sessay, S. Wokabi. (2007) The GEFSOC soil carbon modelling system: A tool for conducting regional-scale soil carbon inventories and assessing the impacts of land use change on soil carbon, Agric. Ecosyst. Environ. 122, 13-25. DOI: 10.1016/j.agee.2007.01.004

Eckersten H., C. Beier. (1998) Comparison of N and C dynamics in two Norway spruce stands using a process oriented simulation model, Environ. Pollut. 102, 395-401. DOI: 10.1016/S0269-7491(98)80059-6

Eckersten H., K. Blombäck, T. Kätterer, P. Nyman. (2001) Modelling C, N, water and heat dynamics in winter wheat under climate change in southern Sweden, Agric. Ecosyst. Environ. 86, 221-235. DOI: $10.1016 / \mathrm{S} 0167-8809(00) 00284-\mathrm{X}$

Ellert B.H., E.G. Gregorich. (1996) Storage of carbon, nitrogen and phosphorus in cultivated and adjacent forested soils of Ontario, Soil Sci. 161, 587-603. DOI: 00010694-199609000-00004.

Elliott E.T., K. Paustian, S.D. Frey. (1996) Modeling the measurable or measuring the modelable: a hierarchical approach to isolating meaningful soil organic matter fractions, in: D.S. Powlson, P. Smith, J.U. Smith (Eds.), Evaluation of soil organic matter models. Using existing long-term datasets, Springer, Heidelberg, pp. 429.

Epron D., Y. Nouvellon, O. Roupsard, W. Mouvondy, A. Mabiala, L. Saint-André, R. Joffre, C. Jourdan, J.-M. Bonnefond, P. Berbigier, O. Hamel. (2004) Spatial and temporal variations of soil respiration in a Eucalyptus plantation in Congo, Forest Ecol. Manage. 202, 149-160. DOI: 10.1016/j.foreco.2004.07.019.

Feigl B., J. Melillo, C. Cerri. (1995) Changes in the origin and quality of soil organic matter after pasture introduction in Rondônia (Brazil), Plant and Soil 175, 21-29. DOI: 10.1007/BF02413007.

Feller C., M.H. Beare. (1997) Physical control of soil organic matter dynamics in the tropics, Geoderma 79, 69116. DOI: 10.1016/S0016-7061(97)00039-6.

Fenchel T., G.M. King, T.H. Blackburn. (1998) Bacterial biogeochemistry. The ecophysiology of mineral cycling. Academic Press, San Diego, California (US).

Fernandes E.C.M., P.P. Motavalli, C. Castilla, L. Mukurumbira. (1997) Management control of soil organic matter dynamics in tropical land-use systems, Geoderma 79, 49-67. DOI: 10.1016/S00167061(97)00038-4.

Findeling A., P. Garnier, F. Coppens, F. Lafolie, S. Recous. (2007) Modelling water, carbon and nitrogen dynamics in soil covered with decomposing mulch, Eur. J. Soil Sci. 58, 196-206. DOI: 10.1111/j.13652389.2006.00826.x. 
Franko U. (1996) Modelling approaches of soil organic matter within the CANDY system, in: D.S. Powlson, P. Smith, J.U. Smith (Eds.), Evaluation of soil organic matter models using existing, long-term datasets, NATO ASI, I38. Springer, Berlin, pp. 247-254.

Franko U., G.J. Crocker, P.R. Grace, J. Klír, M. Körschens, P.R. Poulton, D.D. Richter. (1997) Simulating trends in soil organic carbon in long-term experiments using the CANDY model, Geoderma 81, 109120. DOI: 10.1016/S0016-7061(97)00084-0.

Franko U., B. Oelschlägel, S. Schenk. (1995) Simulation of temperature, water- and nitrogen dynamics using the model CANDY, Ecol. Modell. 81, 213-222. DOI: 10.1016/0304-3800(94)00172-E

Frolking S., N.T. Roulet, T.R. Moore, P.J.H. Richard, M. Lavoie, S.D. Muller. (2001) Modeling northern peatland decomposition and peat accumulation, Ecosyst. 4, 479-498. DOI: 10.1007/s.10021-001-0105-1.

Furniss P.R., P. Ferrar, J.W. Morris, J.J. Bezuidenhout. (1982) A model of savannah litter decomposition, Ecol. Modell. 17, 33-51. DOI: 10.1016/0304-3800(82)90085-0.

García-Oliva F., I. Casar, P. Morales, J.M. Maass. (1994) Forest-to-pasture conversion influences on soil organic carbon dynamics in a tropical deciduous forest, Oecologia 99, 392-396. DOI: 10.1007/BF00627754.

García-Oliva F., R.L. Sanford, E. Kelly. (1999) Effects of slash-and-burn management on soil aggregate organic $\mathrm{C}$ and $\mathrm{N}$ in a tropical deciduous forest, Geoderma 88, 1-12. DOI: 10.1016/S0016-7061(98)00063-9.

Garnier P., C. Néel, C. Aita, S. Recous, F. Lafolie, B. Mary. (2003) Modelling carbon and nitrogen dynamics in a bare soil with and without straw incorporation, Eur. J. Soil Sci. 54, 555-568. DOI: 10.1046/j.13652389.2003.00499.x.

Garnier P., C. Néel, B. Mary, F. Lafolie. (2001) Evaluation of a nitrogen transport and transformation model in a bare soil, Eur. J. Soil Sci. 52, 253-268. DOI: 10.1046/j.1365-2389.2001.00374.x.

Gignoux J., J. House, D. Hall, D. Masse, H.B. Nacro, L. Abbadie. (2001) Design and test of a generic cohort model of soil organic matter decomposition: the SOMKO model, Gl. Ecol. Biogeography 10, 639-660. DOI: 10.1046/j.1466-822X.2001.t01-1-00250.X.

Goulden M.L., S.D. Miller, H.R. da Rocha, M.C. Menton, H.C. de Freitas, A.M. e Silva Figueira, C.A.D. de Sousa. (2004) Diel and seasonal patterns of tropical forest $\mathrm{CO}_{2}$ exchange, Ecol. Appl. 14, 42-54. DOI: $10.1890 / 02-6008$.

Groffman P.M., N.J. Boulware, W.C. Zipperer, R.V. Pouyat, L.E. Band, M.F. Colosimo. (2002) Soil nitrogen cycle processes in urban riparian zones, Environ. Sci. Technol. 36, 4547-4552. DOI: 10.1021/es020649z.

Hadas A., L. Kautsky, M. Goek, E. Erman Kara. (2004) Rates of decomposition of plant residues and available nitrogen in soil, related to residue composition through simulation of carbon and nitrogen turnover, Soil Biol. Biochem. 36, 255-266. DOI: 10.1016/j.soilbio.2003.09.012.

Hansen S., H.E. Jensen, N.E. Nielsen, H. Svendsen. (1991) Simulation of nitrogen dynamics and biomass production in winter wheat using the Danish simulation model DAISY, Fert. Res. 27, 245-259. DOI: 10.1007/BF01051131.

Hattermann F., V. Krysanova, F. Wechsung, M. Wattenbach. (2004) Integrating groundwater dynamics in regional hydrological modelling, Environ. Model. Software 19, 1039-1051. DOI: 10.1016/j.envsoft.2003.11.007.

Henriksen T.M., T.A. Breland. (1999) Evaluation of criteria for describing crop residue degradability in a model of carbon and nitrogen turnover in soil, Soil Biol. Biochem. 31, 1135-1149. DOI: 10.1016/S003807117(99)00031-o.

Houghton R.A. (2002) The global effects of tropical deforestation, Environ. Sci. Technol. 24, 414-422. DOI: 10.1021/es00074a001. 
Houghton R.A., D.S. Lefkowitz, D.L. Skole. (1991) Changes in the landscape of Latin America between 1850 and 1985 I. Progressive loss of forests, Forest Ecol. Manage. 38, 143-172. DOI: 10.1016/03781127(91)90140-Q.

Howard D.M., P.J.A. Howard. (1993) Relationships between $\mathrm{CO}_{2}$ evolution, moisture content and temperature for a range of soil types, Soil Biol. Biochem. 25, 1537-1546. DOI: 10.1016/0038-0717(93)90008Y.

Hunt H.W., M.J. Trlica, E.F. Redente, J.C. Moore, J.K. Detling, T.G.F. Kittel, D.E. Walter, M.C. Fowler, D.A. Klein, E.T. Elliott. (1991) Simulation model for the effects of climate change on temperate grassland ecosystems, Ecol. Modell. 53, 205-246. DOI: 10.1016/0304-3800(91)90157-V

IPCC. (2003) Good practice guidance for land use, land use change and forestry, in: J. Penman, M. Gytarsky, T. Hiraishi, T. Krug, T. Kruger, R. Pipatti, L. Buendia, K. Miwa, T. Ngara, K. Tanabe, F. Wagner (Eds.), Intergovernmental Pannel on Climate Change, Hayama, Kanagawa (Japan), pp. 599.

Islam K.R., M. Kamaluddin, M.K. Bhuiyan, A. Badruddin. (1999) Comparative performance of exotic and indigenous forest species for tropical semievergreen degraded forest land reforestation in Chittagong, Bangladesh, Land Degr. Dev. 10, 241-249. DOI: 10.1002/(SICI)1099145X(199905/06)10:3<241::AID-LDR335>3.0.CO;2-8.

Islam K.R., R.R. Weil. (2000) Land use effects on soil quality in a tropical forest ecosystem of Bangladesh, Agric. Ecosyst. Environ. 79, 9-16. DOI: 10.1016/S0167-8809(99)00145-0.

Ito A. (2007) Simulated impacts of climate and land-cover change on soil erosion and implication for the carbon cycle, 1901 to 2100, Geophys. Res. Lett. 34. DOI: 10.1029/2007GL029342.

Jenkinson D.S. (1990) The turnover of organic carbon and nitrogen in soil, Phil. Trans. R. Soc. Lond. B 329, 361-368. DOI: 10.1098/rstb.1990.0177.

Jenkinson D.S., D.E. Adams, A. Wild. (1991) Model estimates of $\mathrm{CO}_{2}$ emissions from soil in response to global warming, Nature 351, 304-306. DOI: 10.1038/351304a0.

Jenkinson D.S., K. Coleman. (2008) The turnover of organic carbon in subsoils. Part 2. Modelling carbon turnover, Eur. J. Soil Sci. 59, 400-413. DOI: 10.1111/j.1365-2389.2008.01026.x.

Jenkinson D.S., J.H. Rayner. (1977) The turnover of soil organic matter in some of the Rothamsted classical experiments, Soil Sci. 123, 298-305. DOI: 00010694-197705000-00005.

Jensen L.S., T. Mueller, N.E. Nielsen, S. Hansen, G.J. Crocker, P.R. Grace, J. Klír, M. Körschens, P.R. Poulton. (1997) Simulating trends in soil organic carbon in long-term experiments using the soil-plantatmosphere model DAISY, Geoderma 81, 5-28. DOI: 10.1016/S0016-7061(97)88181-5

Johnson D.W. (1992) Effects of forest management on soil carbon storage, Water Air Soil Pollut. 64, 83-120. DOI: $10.1007 / \mathrm{BF} 00477097$.

Johnsson H., L. Bergstrom, P.-E. Jansson, K. Paustian. (1987) Simulated nitrogen dynamics and losses in a layered agricultural soil, Agric. Ecosyst. Environ. 18, 333-356. DOI: 10.1016/0167-8809(87)90099-5

Juo A.S., R. Lal. (1979) Nutrient profile in a tropical alfisol under conventional and no-till systems, Soil Sci. 127, 168-173. DOI: 00010694-197903000-00006.

Kaonga M.L., K. Coleman. (2008) Modelling soil organic carbon turnover in improved fallows in eastern Zambia using the RothC-26.3 model, Forest Ecol. Manage. 256, 1160-1166. DOI: 10.1016/j.foreco.2008.06.017

Kelly R.H., W.J. Parton, G.J. Crocker, P.R. Graced, J. Klír, M. Körschens, P.R. Poulton, D.D. Richter. (1997) Simulating trends in soil organic carbon in long-term experiments using the century model, Geoderma 81, 75-90. DOI: 10.1016/S0016-7061(97)00082-7

Kersebaum K.C., J. Richter. (1991) Modelling nitrogen dynamics in a plant-soil system with a simple model for advisory purposes, Nutr. Cycling Agroecosyst. 27, 273-281. DOI: 10.1007/BF01051133.

Kieft T.L., E. soroker, M.K. firestone. (1987) Microbial biomass response to a rapid increase in water potential when dry soil is wetted, Soil Biol. Biochem. 19, 119-126. DOI: 10.1016/0038-0717(87)90070-8. 
Kieft T.L., C.S. White, S.R. Loftin, R. Aguilar, J.A. Craig, D.A. Skaar. (1998) Temporal dynamics in soil carbon and nitrogen resources at a grassland-shrubland ecotone, Ecology 79, 671-683. DOI: 10.1890/0012-9658(1998)079[0671:TDISCA]2.0.CO;2.

Kiese R., K. Butterbach-Bahl. (2002) $\mathrm{N}_{2} \mathrm{O}$ and $\mathrm{CO}_{2}$ emissions from three different tropical forest sites in the wet tropics of Queensland, Australia, Soil Biol. Biochem. 34, 975-987. DOI: 10.1016/S00380717(02)00031-7.

Killham K., R. Foster. (1994) Soil ecology. Cambridge University Press, Cambridge (UK).

Kirschbaum M.U.F., K.I. Paul. (2002) Modelling C and N dynamics in forest soils with a modified version of the CENTURY model, Soil Biol. Biochem. 34, 341-354. DOI: 10.1016/S0038-0717(01)00189-4.

Koch O., D. Tscherko, E. Kandeler. (2007) Temperature sensitivity of microbial respiration, nitrogen mineralization, and potential soil enzyme activities in organic alpine soils, Global Biogeochem. Cycles 21. DOI: 10.1029/2007GB002983.

Krysanova V., A. Meiner, J. Roosaare, A. Vasilyev. (1989) Simulation modelling of the coastal waters pollution from agricultural watershed, Ecol. Modell. 49, 7-29. DOI: 10.1016/0304-3800(89)90041-0.

Krysanova V., D.-I. Müller-Wohlfeil, A. Becker. (1998) Development and test of a spatially distributed hydrological/water quality model for mesoscale watersheds, Ecol. Modell. 106, 261-289. DOI: 10.1016/S0304-3800(97)00204-4

Kuijper L.D.J., M.P. Berg, E. Morriën, B.W. Kooi, H.A. Verhoef. (2005) Global change effects on a mechanistic decomposer food web model, Global Change Biol. 11, 249-265. DOI: 10.1111/j.13652486.2005.00898.x.

Lafolie F. (1991) Modelling water flow, nitrogen transport and root uptake including physical non-equilibrium and optimization of the root water potential, Fert. Res. 27, 215-231. DOI: 10.1007/BF01051129.

Laio F., A. Porporato, L. Ridolfi, I. Rodriguez-Iturbe. (2001) Plants in water-controlled ecosystems: active role in hydrological processes and response to water stress. II. Probabilistic soil moisture dynamics, Adv. Water Res. 24, 707-723. DOI: 10.1016/S0309-1708(01)00005-7

Landsberg J.J., R.H. Waring. (1997) A generalised model of forest productivity using simplified concepts of radiation-use efficiency, carbon balance and partitioning, Forest Ecol. Manage. 95, 209-228. DOI: 10.1016/S0378-1127(97)00026-1

Li C., S. Frolking, R. Harriss. (1994) Modeling carbon biogeochemistry in agricultural soils, Global Biogeochem. Cycles 8, 237-254. DOI: 10.1029/94GB00767.

Lugo A., S. Brown. (1993) Management of tropical soils as sinks or sources of atmospheric carbon, Plant and Soil 149, 27-41. DOI: 10.1007/BF00010760.

Lutz H.J., R.F. Chandler. (1955) Forest soils. John Willey, New York (US).

Maggi F., C. Gu, W.J. Riley, G.M. Hornberger, R.T. Venterea, T. Xu, N. Spycher, C. Steefel, N.L. Miller, C.M. Oldenburg. (2008) A mechanistic treatment of the dominant soil nitrogen cycling processes: Model development, testing, and application, J. Geophys. Res. 113. DOI: 10.1029/2007JG000578.

Mann L.K. (1986) Changes in soil carbon storage after cultivation, Soil Sci. 142, 279-288. DOI: 00010694198611000-00006.

Manzoni S., A. Porporato. (2007) A theoretical analysis of nonlinearities and feedbacks in soil carbon and nitrogen cycles, Soil Biol. Biochem. 39, 1542-1556. DOI: 10.1016/j.soilbio.2007.01.006.

Manzoni S., A. Porporato. (2009) Soil carbon and nitrogen mineralization: Theory and models across scales, Soil Biol. Biochem. 41, 1355-1379. DOI: 10.1016/j.soilbio.2009.02.031.

Martins P.F.S., C.C. Cerri, B. Volkoff, F. Andreux, A. Chauvel. (1991) Consequences of clearing and tillage on the soil of a natural Amazonian ecosystem, Forest Ecol. Manage. 38, 273-282. DOI: 10.1016/03781127(91)90148-O. 
Matus F.J., J. Rodríguez. (1994) A simple model for estimating the contribution of nitrogen mineralization to the nitrogen supply of crops from a stabilized pool of soil organic matter and recent organic input, Plant and Soil 162, 259-271. DOI: 10.1007/BF01347713.

Melillo J.M. (1996) Carbon and nitrogen interactions in the terrestrial biosphere: Anthropogenic effects, in: B. Walker, W. Steffen (Eds.), Gl. Ch. Ter. Ecosyst., Cambridge University Press, Cambridge (UK), pp. 431-450.

Mirschel W., H. Kretschmer, E. Matthäus, R. Koitzsch. (1991) Simulation of the effects of nitrogen supply on yield formation processes in winter wheat with the model TRITSIM, Fert. Res 27, 293-304. DOI: 10.1007/BF01051135.

Misson L., J. Tang, M. Xu, M. McKay, A. Goldstein. (2005) Influences of recovery from clear-cut, climate variability, and thinning on the carbon balance of a young ponderosa pine plantation, Agric. For. Meteorol. 130, 207-222. DOI: 10.1016/j.agrformet.2005.04.001.

Molina J.A.E., C.E. Clapp, M.J. Shaffer, F.W. Chichester, W.E. Larson. (1983) NCSOIL, a model of nitrogen and carbon transformations in soil: description, calibration and behavior, Soil Sci. Soc. Am. J. 47, 8591.

Moore J.C., E.L. Berlow, D.C. Coleman, P.C. Ruiter, Q. Dong, A. Hastings, N.C. Johnson, K.S. McCann, K. Melville, P.J. Morin, K. Nadelhoffer, A.D. Rosemond, D.M. Post, J.L. Sabo, K.M. Scow, M.J. Vanni, D.H. Wall. (2004) Detritus, trophic dynamics and biodiversity, Ecol. Lett. 7, 584-600. DOI: 10.1111/j.1461-0248.2004.00606.x.

Moore J.C., K. McCann, P.C. de Ruiter. (2005) Modeling trophic pathways, nutrient cycling, and dynamic stability in soils, Pedobiologia 49, 499-510. DOI: 10.1016/j.pedobi.2005.05.008.

Moore T.R., J.A. Trofymow, M. Siltanen, L.M. Kozak. (2008) Litter decomposition and nitrogen and phosphorous dynamics in peatlands and uplands over 12 years in central Canada, Oecologia 157, 317-325. DOI: $10.1007 / \mathrm{s} 00442-008-1076-0$.

Moorhead D.L., W.S. Currie, E.B. Rastetter, W.J. Parton, M.E. Harmon. (1999) Climate and litter quality controls on decomposition: An analysis of modeling approaches, Global Biogeochem. Cycles 13, 575-589. DOI: $10.1029 / 1998 G B 900014$.

Moorhead D.L., J.F. Reynolds. (1991) A general model of litter decomposition in the northern Chihuahuan Desert, Ecol. Modell. 56, 197-219. DOI: 10.1016/0304-3800(91)90200-K

Motavalli P.P., H. Discekici, J. Kuhn. (2000) The impact of land clearing and agricultural practices on soil organic $\mathrm{C}$ fractions and $\mathrm{CO}_{2}$ efflux in the Northern Guam aquifer, Agric. Ecosyst. Environ. 79, 17-27. DOI: 10.1016/S0167-8809(99)00139-5.

Murty D., M.U.F. Kirschbaum, R.E. McMurtrie, H. McGilvray. (2002) Does conversion of forest to agricultural land change soil carbon and nitrogen? a review of the literature, Global Change Biol. 8, 105-123. DOI: 10.1046/j.1354-1013.2001.00459.x.

Ndiaye B., J. Molénat, V. Hallaire, C. Gascuel, Y. Hamon. (2007) Effects of agricultural practices on hydraulic properties and water movement in soils in Brittany (France), Soil Till. Res. 93, 251-263. DOI: 10.1016/j.still.2006.04.005.

Neel C. (1996) Modélisation couplée du transfert et des transformations de l'azote: Paramétrisation et évaluation d'un modèle en sol nu, Université Pierre et Marie Curie, Paris, pp. 276.

Nicolardot B., S. Recous, B. Mary. (2001) Simulation of C and N mineralisation during crop residue decomposition: A simple dynamic model based on the C:N ratio of the residues, Plant and Soil 228, 83-103. DOI: $10.1023 / \mathrm{A}: 1004813801728$.

Nye P.H., D.J. Greenland. (1964) Changes in the soil after clearing tropical forest, Plant and Soil 21, 101-112. DOI: $10.1007 / \mathrm{BF} 01373877$.

O'Brien B.J. (1984) Soil organic carbon fluxes and turnover rates estimated from radiocarbon enrichments, Soil Biol. Biochem. 16, 115-120. DOI: 10.1016/0038-0717(84)90100-7. 
Pansu M., P. Bottner, L. Sarmiento, K. Metselaar. (2004) Comparison of five soil organic matter decomposition models using data from a ${ }^{14} \mathrm{C}$ and ${ }^{15} \mathrm{~N}$ labeling field experiment, Global Biogeochem. Cycles 18, GB4022. DOI: 10.1029/2004GB002230.

Pansu M., Z. Sallih, P. Bottner. (1998) Modelling of soil nitrogen forms after organic amendments under controlled conditions, Soil Biol. Biochem. 30, 19-29. DOI: 10.1016/S0038.0717(97)00087-4.

Pansu M., L. Sarmiento, K. Metselaar, D. Hervé, P. Bottner. (2007) Modelling the transformations and sequestration of soil organic matter in two contrasting ecosystems of the Andes, Eur. J. Soil Sci. 58, 775-785. DOI: 10.1111/j.1365-2389.2006.00867.x.

Parton W.J., P.E. Rassmussen. (1994) Long-term effects of crop management in wheat-fallow: II. CENTURY model simulations, Soil Sci. Soc. Am. J. 58, 530-536.

Parton W.J., D.S. Schimmel, C.V. Cole, D.S. Ojima. (1987) Analysis of factors controlling soil organic matter levels in great plains grasslands, Soil Sci. Soc. Am. J. 51, 1173-1179.

Parton W.J., J.M.O. Scurlock, D.S. Ojima, T.G. Gilmanov, R.J. Scholes, D.S. Schimel, T. Kirchner, J.C. Menaut, T. Seastedt, E. Garcia Moya, A. Kamnalrut, J.I. Kinyamario. (1993) Observations and modeling of biomass and soil organic matter dynamics for the frassland biome worldwide, Global Biogeochem. Cycles 7, 785-809. DOI: 10.1029/93GB02042.

Pastor J., W. Post. (1986) Influence of climate, soil moisture, and succession on forest carbon and nitrogen cycles, Biogeochemistry 2, 3-27. DOI: 10.1007/BF02186962.

Paul E.A. (1976) Carbon, nitrogen, phosphorous, sulfur and selenium cycles, Proc. $2^{\text {nd }}$ Int. Symp. Environ. Biogechem.

Paul K.I., P.J. Polglase. (2004) Prediction of decomposition of litter under eucalypts and pines using the FullCAM model, Forest Ecol. Manage. 191, 73-92. DOI: 10.1016/j.foreco.2003.11.007

Paustian K., O. Andren, M. Clarholm, A.C. Hansson, G. Johansson, J. Lagerlof, T. Lindberg, R. Pettersson, B. Sohlenius. (1990) Carbon and nitrogen budgets of four agro-ecosystems with annual and perennial crops, with and without $\mathrm{N}$ fertilization, J. Appl. Ecol. 27, 60-84.

Peng C., M.J. Apps, D.T. Price, I.A. Nalder, D.H. Halliwell. (1998) Simulating Carbon Dynamics Along the Boreal Forest Transect Case Study (BFTCS) in Central Canada 1. Model Testing, Gl. Biogeochem. Cycles 12, 381-402. DOI: 10.1029/98GB00351.

Peng C., J. Liu, Q. Dang, M.J. Apps, H. Jiang. (2002) TRIPLEX: a generic hybrid model for predicting forest growth and carbon and nitrogen dynamics, Ecol. Modell. 153, 109-130. DOI: 10.1016/S03043800(01)00505-1

Persson T. (1983) Influence of soil animals on nitrogen mineralisation in a northern Scots pine forest, in: P. Lebrun, H.M. Andre, A. de Medts, C. Gregoire-Wibo, G. Wauthy (Eds.), Proc. of the VIII Int. Colloquium of soil Zoology, Louvain-la-Neuve (Belgium).

Pietikåinen J., M. Pettersson, E. Bååth. (2005) Comparison of temperature effects on soil respiration and bacterial and fungal growth rates, FEMS Microbiol. Ecol. 52, 49-58. DOI: 10.1016/j.femsec.2004.10.002

Porporato A., P. D'Odorico, F. Laio, I. Rodriguez-Iturbe. (2003) Hydrologic controls on soil carbon and nitrogen cycles. I. Modelling scheme, Adv. Water Res. 26, 45-58. DOI: 10.1016/S0309-1708(02)00094-5.

Post J., V. Krysanova, F. Suckow, W. Mirschel, J. Rogasik, I. Merbach. (2007) Integrated eco-hydrological modelling of soil organic matter dynamics for the assessment of environmental change impacts in meso- to macro-scale river basins, Ecol. Modell. 206, 93-109. DOI: 10.1016/j.ecolmodel.2007.03.028

Post W.M., W.R. Emanuel, P.J. Zinke, A.G. Stangenberger. (1982) Soil carbon pools and world life zones, Nature 298, 156-159. DOI: 10.1038/298156a0.

Prasad P., S. Basu, N. Behera. (1995) A comparative account of the microbiological characteristics of soils under natural forest, grassland and cropfield from Eastern India, Plant and Soil 175, 85-91. DOI: 10.1007/BF02413013. 
Prober S.M., K.R. Thiele, L.T.B. Koen. (2005) Restoring ecological function in temperate grassy woodlands: manipulating soil nutrients, exotic annuals and native perennial grasses through carbon supplements and spring burns, J. Appl. Ecol. 42, 1073-1085.

Pruess K., C.M. Oldenburg, G.J. Moridis (1999) TOUGH2 user's guide version 2, Lawrence Berkeley National Laboratory, University of California, Berkeley, California (US), pp. 192.

Reichstein M., A. Rey, A. Freibauer, J. Tenhunen, R. Valentini, J. Banza, P. Casals, Y. Cheng, J.M. GrÃ̄1/4nzweig, J. Irvine, R. Joffre, B.E. Law, D. Loustau, F. Miglietta, W. Oechel, J.-M. Ourcival, J.S. Pereira, A. Peressotti, F. Ponti, Y. Qi, S. Rambal, M. Rayment, J. Romanya, F. Rossi, V. Tedeschi, G. Tirone, M. Xu, D. Yakir. (2003) Modeling temporal and large-scale spatial variability of soil respiration from soil water availability, temperature and vegetation productivity indices, Global Biogeochem. Cycles 17, 1104. DOI: 10.1029/2003gb002035.

Reicosky D.C., W.A. Dugas, H.A. Torbert. (1997) Tillage-induced soil carbon dioxide loss from different cropping systems, Soil Till. Res. 41, 105-118. DOI: 10.1016/S0167-1987(96)01080-X

Reiners W.A., A.F. Bouwman, W.F.J. Parsons, M. Keller. (1994) Tropical Rain Forest Conversion to Pasture: Changes in Vegetation and Soil Properties, Ecol. Appl. 4, 363-377.

Rey A., E. Pegoraro, V. Tedeschi, I. De Parri, P. Jarvis, R. Valentini. (2002) Annual variation in soil respiration and its components in a coppice oak forest in Central Italy, Global Change Biol. 8, 851-866. DOI: 10.1046/j.1365-2486.2002.00521.x.

Richards G.P. (2001) The FullCAM carbon accounting model: development, calibration and implementation for the national carbon accounting system, Australian Greenhouse Office, Canberra (Australia), pp. 6-27.

Richards G.P., D. Evans (2000) Carbon accounting model for forests (CAMFor). User manual version 3.5, Australian Greenhouse Office, Canberra, Australia, pp. 64.

Rodrigo A., S. Recous, C. Neel, B. Mary. (1997) Modelling temperature and moisture effects on C-N transformations in soils: comparison of nine models, Ecol. Modell. 102, 325-339. DOI: 10.1016/S03043800(97)00067-7

Rodriguez-Iturbe I., A. Porporato. (2004) Ecohydrology of water-controlled ecosystems. Soil moisture and plant dynamics. Cambridge University Press, Cambridge (UK).

Rodriguez-Iturbe I., A. Porporato, F. Laio, L. Ridolfi. (2001) Plants in water-controlled ecosystems: active role in hydrologic processes and response to water stress: I. Scope and general outline, Adv. Water Res. 24, 695-705. DOI: 10.1016/S0309-1708(01)00004-5.

Roger-Estrade J., G. Richard, J. Caneill, H. Boizard, Y. Coquet, P. Defossez, H. Manichon. (2004) Morphological characterisation of soil structure in tilled fields: from a diagnosis method to the modelling of structural changes over time, Soil Till. Res. 79, 33-49. DOI: 10.1016/j.still.2004.03.009

Rustad L.E., T.G. Huntington, R.D. Boone. (2000) Controls on soil respiration: Implications for climate change, Biogeochemistry 48, 1-6. DOI: 10.1023/A:1006255431298.

Ryel R.J., A.J. Leffler, M.S. Peek, C.Y. Ivans, M.M. Caldwell. (2004) Water conservation in Artemisia tridentata through redistribution of precipitation, Oecologia 141, 335-345. DOI: 10.1007/s00442-003-1421-2.

Sallih Z., M. Pansu. (1993) Modelling of soil carbon forms after organic amendment under controlled conditions, Soil Biol. Biochem. 25, 1755-1762. DOI: 10.1016/0038-0717(93)90180-J.

Savage K.E., E.A. Davidson. (2001) Interannual variation of soil respiration in two New England forests, Global Biogeochem. Cycles 15, 337-350. DOI: 10.1029/1999gb001248.

Schimel D.S., B.H. Braswell, E.A. Holland, R. McKeown, D.S. Ojima, T.H. Painter, W.J. Parton, A.R. Townsend. (1994) Climatic, Edaphic, and Biotic Controls Over Storage and Turnover of Carbon in Soils, Global Biogeochem. Cycles 8, 279-293. DOI: 10.1029/94GB00993.

Schinner F., E. Kandeler, R. Öhlinger, R. Margesin. (1995) Methods in soil biology. Springer-Verlag, Berlin, New York. 
Schlesinger W.H., J.A. Andrews. (2000) Soil Respiration and the Global Carbon Cycle, Biogeochemistry 48, 720. DOI: $10.1023 / A .1006247623877$.

Scholes M.C., D. Powlson, G. Tian. (1997) Input control of organic matter dynamics, Geoderma 79, 25-47. DOI: 10.1016/S0016-7061(97)00037-2.

Schwinning S., O.E. Sala. (2004) Hierarchy of responses to resource pulses in arid and semi-arid ecosystems, Oecologia 141, 211-220. DOI: 10.1007/s00442-004-1520-8.

Schwinning S., B.I. Starr, J.R. Ehleringer. (2003) Dominant cold desert plants do not partition warm season precipitation by event size, Oecologia 136, 252-260. DOI: 10.1007/s00442-003-1255-y.

Scott-Denton L.E., T.N. Rosenstiel, R.K. Monson. (2006) Differential controls by climate and substrate over the heterotrophic and rhizospheric components of soil respiration, Global Change Biol. 12, 205-206. DOI: 10.111/j.1365-2486.2005.01065.x.

Shaffer M.J., A.D. Halvorson, F.J. Pierce. (1991) Nitrate leaching and economic analysis package (NLEAP): model description and application, in: R.F. Follet (Ed.) Managing nitrogen for groundwater quality and farm profitability, ASA, Madison, Wisconsin (US), pp. 285-232.

Smil V. (1999) Crop Residues: Agriculture's Largest Harvest, Bioscience 49, 299-308.

Smith P., O. Andrén, L. Brussaard, M. Dangerfield, K. Ekschmitt, P. Lavelle, K. Tate. (1998) Soil biota and global change at the ecosystem level: describing soil biota in mathematical models, Global Change Biol. 4, 773-784. DOI: 10.1046/j.1365-2486.1998.00193.x.

Smith P., J.U. Smith, D.S. Powlson, W.B. McGill, J.R.M. Arah, O.G. Chertov, K. Coleman, U. Franko, S. Frolking, D.S. Jenkinson, L.S. Jensen, R.H. Kelly, H. Klein-Gunnewiek, A.S. Komarov, C. Li, J.A.E. Molina, T. Mueller, W.J. Parton, J.H.M. Thornley, A.P. Whitmore. (1997) A comparison of the performance of nine soil organic matter models using datasets from seven long-term experiments, Geoderma 81, 153-225. DOI: 10.1016/S0016-7061(97)00087-6

Stark J.M., M.K. Firestone. (1995) Mechanisms for soil moisture effects on activity of nitrifying bacteria, Appl. Environ. Microbiol. 61, 218-221.

Stevenson F.J., M.A. Cole. (1999) Cycles of soil. Carbon, nitrogen, phosphorous, sulfur, micronutrients. John Wiley \& Sons, New York (US).

Thornley J.H.M. (1991) A transport-resistance model of forest growth and partitioning, Ann. Bot. 68, 211-226.

Thornley J.H.M., J. Bergelson, A.J. Parsons. (1995) Complex dynamics in a carbon-nitrogen model of a grasslegume pasture, Ann. Bot. 75, 79-94.

Van Gestel M., R. Merckx, K. Vlassak. (1993) Microbial biomass responses to soil drying and rewetting: The fate of fast- and slow-growing microorganisms in soils from different climates, Soil Biol. Biochem. 25, 109-123. DOI: 10.1016/0038-0717(93)90249-B

Veldkamp E. (1994) Organic carbontTurnover in three tropical soils under pasture after deforestation, Soil Sci. Soc. Am. J. 58, 175-180.

Verberne E.L., J. Hassink, P. De Willigen, J.J.R. Groot, J. Van Veen. (1990) Modelling organic matter dynamics in different soils, Neth. J. Agric. Sci. 38, 221-238.

Verhoef H., L. Brussaard. (1990) Decomposition and nitrogen mineralization in natural and agroecosystems: the contribution of soil animals, Biogeochemistry 11, 175-211. DOI: 10.1007/BF00004496.

Vitousek P.M. (1984) Litterfall, nutrient cycling, and nutrient limitation in tropical forests, Ecology 65, 285298. DOI: $10.2307 / 1939481$.

Vitousek P.M., R.L. Sanford. (1986) Nutrient cycling in moist tropical forest, Ann. Rev. Ecol. Systematics 17, 137. DOI: 10.1146/annurev.es.17.110186.001033. 
Wattenbach M., F. Hattermann, R. Weng, F. Wechsung, V. Krysanova, F. Badeck. (2005) A simplified approach to implement forest eco-hydrological properties in regional hydrological modelling, Ecol. Modell. 187, 40-59. DOI: 10.1016/j.ecolmodel.2005.01.026

White R.E. (1997) Principles and practice of soil science. Blackwell Science, Oxford (UK).

Wolf J., C. De Wit, H. Van Keulen. (1989) Modeling long-term crop response to fertilizer and soil nitrogen. I. Model description and application, Plant and Soil 120, 11-22. DOI: 10.1007/BF02370286.

Wolf J., H. Van Keulen. (1989) Modeling long-term crop response to fertilizer and soil nitrogen. II. Comparison with field results, Plant and Soil 120, 23-38. DOI: 10.1007/BF02370287.

Xu L., D.D. Baldocchi, J. Tang. (2004) How soil moisture, rain pulses, and growth alter the response of ecosystem respiration to temperature, Global Biogeochem. Cycles 18. DOI: 10.1029/2004GB002281.

Xu T., E. Sonnenthal, N. Spycher, K. Pruess. (2006) TOUGHREACT--A simulation program for nonisothermal multiphase reactive geochemical transport in variably saturated geologic media: Applications to geothermal injectivity and $\mathrm{CO}_{2}$ geological sequestration, Comput. Geosci. 32, 145-165. DOI: 10.1016/j.cageo.2005.06.014.

Young A., R. Young. (2001) Soils in the Australian landscape. Oxford University Press, Victoria (Australia).

Young T.P., D.A. Petersen, J.J. Clary. (2005) The ecology of restoration: historical links, emerging issues and unexplored realms, Ecol. Lett. 8, 662-673. DOI: 10.1111/j.1461-0248.2005.00764.x.

Zelenev V.V., A.H.C. van Bruggen, P.A. Leffelaar, J. Bloem, A.M. Semenov. (2006) Oscillating dynamics of bacterial populations and their predators in response to fresh organic matter added to soil: The simulation model "BACWAVE-WEB", Soil Biol. Biochem. 38, 1690-1711. DOI: 10.1016/j.soilbio.2005.11.024.

Zheng D.W., G.I. Agren, J. Bengtsson. (1999) How do soil organisms affect total organic nitrogen storage and substrate nitrogen to carbon ratio in soils? A theoretical analysis, Oikos 86, 430-442. 
Tables

Table 1. Main characteristics of the five most popular models.

\begin{tabular}{|c|c|c|c|}
\hline Model & Type & Characteristics & References to updated versions \\
\hline $\begin{array}{c}\text { CENTURY } \\
\text { Parton et al. (1987) }\end{array}$ & $\begin{array}{l}\text { Process-oriented } \\
\text { multi-compartment }\end{array}$ & $\begin{array}{l}\text { - Long-term (decades to centuries) of } \\
\text { SOM dynamics, plant growth and } \\
\text { cycling of N, P and S, using monthly } \\
\text { input data; } \\
\text { - Three organic compartments: active, } \\
\text { slow and passive; } \\
\text { - Soil texture regulates the C transfer } \\
\text { from one compartment to another. }\end{array}$ & $\begin{array}{l}\text { Parton and Rassmussen (1994) } \\
\text { Fernandes et al. (1997) } \\
\text { Kelly et al. (1997) } \\
\text { Smith et al. (1997) } \\
\text { Bolker et al. (1998) } \\
\text { Peng et al. (1998) } \\
\text { Kirschbaum and Paul (2002) } \\
\text { Easter et al. (2007) }\end{array}$ \\
\hline $\begin{array}{c}\text { DAISY } \\
\text { Hansen et al. (1991) }\end{array}$ & $\begin{array}{l}\text { Process-oriented } \\
\text { multi-compartment }\end{array}$ & $\begin{array}{l}\text { - Simulates crop production, soil wa- } \\
\text { ter and N dynamics; } \\
\text { - Four different modules: hydrologi- } \\
\text { cal, soil temperature, soil nitrogen, } \\
\text { and crop models; } \\
\text { - Decomposition rate constants de- } \\
\text { pend on clay content; } \\
\text { - Vertical soil profile divided in layers } \\
\text { considering physical and chemical } \\
\text { characteristics. }\end{array}$ & $\begin{array}{l}\text { Jensen et al. (1997) } \\
\text { Smith et al. (1997) }\end{array}$ \\
\hline $\begin{array}{c}\text { NCSOIL } \\
\text { Molina et al. (1983) }\end{array}$ & $\begin{array}{l}\text { Process-oriented } \\
\text { multi-compartment }\end{array}$ & $\begin{array}{l}\text { - Simulates } \mathrm{C} \text { and } \mathrm{N} \text { fluxes through } \\
\text { soil microbes and organic compo- } \\
\text { nents; } \\
\text { - Four organic compartments: plant } \\
\text { residues, microbial biomass, humus } \\
\text { and stable organic matter. }\end{array}$ & $\begin{array}{l}\text { Smith et al. (1997) } \\
\text { Hadas et al. (2004) }\end{array}$ \\
\hline $\begin{array}{c}\text { CANDY } \\
\text { (CArbon and Nitrogen } \\
\text { DYnamics) } \\
\text { Franko et al. (1995) }\end{array}$ & $\begin{array}{l}\text { Process-oriented } \\
\text { multi-compartment }\end{array}$ & $\begin{array}{l}\text { - Composed of four different submod- } \\
\text { els: soil temperature, hydrological, } \\
\text { crop and organic matter turnover } \\
\text { models; } \\
\text { - Daily time step; } \\
\text { - Simulates soil N dynamics, tempera- } \\
\text { ture and moisture. }\end{array}$ & $\begin{array}{l}\text { Franko et al. (1996) } \\
\text { Franko et al. (1997) } \\
\text { Smith et al. (1997) }\end{array}$ \\
\hline $\begin{array}{c}\text { RothC } \\
\text { (Rothamsted model) } \\
\text { Jenkinson and Rayner } \\
\text { (1977) }\end{array}$ & $\begin{array}{l}\text { Process-oriented } \\
\text { multi-compartment }\end{array}$ & $\begin{array}{l}\text { - } \mathrm{N} \text { and } \mathrm{C} \text { are not interconnected; } \\
\text { - } \mathrm{C} \text { turnover sensitive to soil type, } \\
\text { temperature, moisture and plant cov- } \\
\text { er; } \\
\text { - Monthly input data. }\end{array}$ & $\begin{array}{c}\text { Smith et al. (1997) } \\
\text { Easter et al. (2007) } \\
\text { Kaonga and Coleman (2008) } \\
\text { Jenkinson and Coleman (2008) }\end{array}$ \\
\hline
\end{tabular}


Table 2. Summary of the main parameters considered in the soil $\mathrm{C}-\mathrm{N}$ model.

\begin{tabular}{|c|c|c|}
\hline Symbol & Representative model parameters & Dimensions \\
\hline$C_{l}$ & Carbon concentration in the litter pool & {$\left[\mathrm{M} \mathrm{L}^{-3}\right]$} \\
\hline$C_{h}$ & Carbon concentration in the humus pool & {$\left[\mathrm{M} \mathrm{L}^{-3}\right]$} \\
\hline$C_{b}$ & Carbon concentration in the biomass pool & {$\left[\mathrm{M} \mathrm{L}^{-3}\right]$} \\
\hline$N_{l}$ & Organic nitrogen concentration in the litter pool & {$\left[\mathrm{M} \mathrm{L}^{-3}\right]$} \\
\hline$N_{h}$ & Organic nitrogen concentration in the humus pool & {$\left[\mathrm{M} \mathrm{L}^{-3}\right]$} \\
\hline$N_{b}$ & Organic nitrogen concentration in the biomass pool & {$\left[\mathrm{M} \mathrm{L}^{-3}\right]$} \\
\hline$N^{+}$ & Ammonium concentration in the soil & {$\left[\mathrm{M} \mathrm{L}^{-3}\right]$} \\
\hline$N$ & Nitrate concentration in the soil & {$\left[\mathrm{M} \mathrm{L}^{-3}\right]$} \\
\hline$A D D$ & External carbon input & {$\left[\mathrm{M} \mathrm{L}^{-2} \mathrm{~T}^{-1}\right]$} \\
\hline$B D$ & $\begin{array}{l}\text { Carbon return to the litter pool due to death of microbial } \\
\text { biomass }\end{array}$ & {$\left[\mathrm{M} \mathrm{L}^{-1}\right]$} \\
\hline$D E C_{l}$ & Carbon output due to microbial decomposition & {$\left[\mathrm{M} \mathrm{L}^{-3} \mathrm{~T}^{-1}\right]$} \\
\hline$D E C_{h}$ & Carbon output due to humus decomposition & {$\left[\mathrm{M} \mathrm{L}^{-3} \mathrm{~T}^{-1}\right]$} \\
\hline$r_{r}$ & Portion of decomposing carbon that is lost by respiration & - \\
\hline$r_{h}$ & $\begin{array}{l}\text { Fraction of decomposing litter which undergoes humifica- } \\
\text { tion }\end{array}$ & - \\
\hline$k_{l}$ & Litter decomposition rate & {$\left[\mathrm{L}^{3} \mathrm{~T}^{-1} \mathrm{M}^{-1}\right]$} \\
\hline$k_{h}$ & Humus decomposition rate & {$\left[\mathrm{L}^{3} \mathrm{~T}^{-1} \mathrm{M}^{-1}\right]$} \\
\hline$k_{d}$ & Biomass death rate & {$\left[\mathrm{T}^{-1}\right]$} \\
\hline$(C / N)_{a d d}$ & Carbon to nitrogen ratio in the external added litter & - \\
\hline$(C / N)_{l}$ & Carbon to nitrogen ratio in the litter pool & - \\
\hline$(C / N)_{h}$ & Carbon to nitrogen ratio in the humus pool & - \\
\hline$(C / N)_{b}$ & Carbon to nitrogen ratio in the biomass pool & - \\
\hline$M I N$ & Mineralization rate & {$\left[\mathrm{T}^{-1} \mathrm{M}^{-1} \mathrm{~L}^{3}\right]$} \\
\hline NIT & Nitrification rate & {$\left[\mathrm{T}^{-1} \mathrm{M}^{-1} \mathrm{~L}^{3}\right]$} \\
\hline$I M M^{+}$ & Ammonium immobilization rate & {$\left[\mathrm{M}^{-1} \mathrm{~L}^{3} \mathrm{~T}^{-1}\right]$} \\
\hline$I M M^{-}$ & Nitrate immobilization rate & {$\left[\mathrm{M}^{-1} \mathrm{~L}^{3} \mathrm{~T}^{-1}\right]$} \\
\hline$L E^{+}$ & Ammonium leaching rate & {$\left[\mathrm{M}^{-1} \mathrm{~L}^{3} \mathrm{~T}^{-1}\right]$} \\
\hline$L E$ & Nitrate leaching rate & {$\left[\mathrm{M}^{-1} \mathrm{~L}^{3} \mathrm{~T}^{-1}\right]$} \\
\hline$U P^{+}$ & Ammonium plant uptake rate & {$\left[\mathrm{M}^{-1} \mathrm{~L}^{3} \mathrm{~T}^{-1}\right]$} \\
\hline$U P^{-}$ & Nitrate plant uptake rate & {$\left[\mathrm{M}^{-1} \mathrm{~L}^{3} \mathrm{~T}^{-1}\right]$} \\
\hline$\Phi$ & $\begin{array}{l}\text { Non-dimensional factor that takes into account the contri- } \\
\text { bution due to either the net mineralization or to the immo- } \\
\text { bilization }\end{array}$ & - \\
\hline$\varphi$ & $\begin{array}{l}\text { Non-dimensional factor that accounts for a possible reduc- } \\
\text { tion of the decomposition rate when the litter is very poor }\end{array}$ & - \\
\hline
\end{tabular}


in $\mathrm{N}$ and the immobilization is not sufficient to integrate the required $\mathrm{N}$ by the bacteria

$f_{d}(s) \quad$ Non-dimensional factor (soil moisture effect on decomposition)

$s \quad$ Soil moisture

$Z_{r} \quad$ Rooting depth 
Table 3. Soil and climate parameters corresponding to the modelled scenarios.

\begin{tabular}{|c|c|c|c|c|}
\hline \multicolumn{3}{|c|}{ Climatic parameters } & $\begin{array}{c}\text { Climate } A \text { (Season- } \\
\text { ality) }\end{array}$ & $\begin{array}{c}\text { Climate } B \text { (no sea- } \\
\text { sonality) }\end{array}$ \\
\hline \multicolumn{2}{|c|}{ Mean storm frequency $(\lambda)$} & $\mathrm{d}^{-1}$ & $0.3,0.1$ & 0.2 \\
\hline \multicolumn{2}{|c|}{ Mean storm [-] depth $(\alpha)$} & $\mathrm{m}$ & $1.55 \times 10^{-2}, 4.8 \times 10^{-3}$ & $1.08 \times 10^{-2}$ \\
\hline \multicolumn{3}{|c|}{$\begin{array}{l}\text { Soil parameters } \\
\end{array}$} & Soil I (agricultural) & Soil II (forest) \\
\hline \multicolumn{2}{|c|}{ Saturated hydraulic conductivity $(K)$} & $\mathrm{m} \mathrm{d}^{-1}$ & 1 & 2 \\
\hline \multicolumn{2}{|c|}{ Active root depth $\left(Z_{r}\right)$} & $\mathrm{m}$ & 0.3 & 0.7 \\
\hline \multicolumn{2}{|c|}{ Pore size distribution index $(b)$} & - & 4.05 & 5.39 \\
\hline \multicolumn{2}{|c|}{ Porosity $(n)$} & - & 0.35 & 0.45 \\
\hline \multicolumn{2}{|c|}{ Tortuosity $(d)$} & - & 1.5 & 3 \\
\hline \multicolumn{2}{|c|}{ Field capacity $\left(s_{f c}\right)$} & - & 0.35 & 0.55 \\
\hline \multirow{7}{*}{ 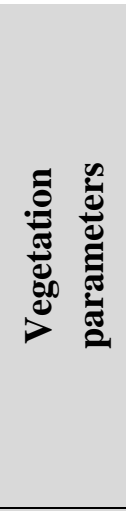 } & Maximum transpiration $\left(T_{\max }\right)$ & $\mathrm{m}$ & $3.6 \times 10^{-3}$ & $4.63 \times 10^{-3}$ \\
\hline & Canopy interception threshold & $\mathrm{m}$ & $5 \times 10^{-4}$ & $2 \times 10^{-3}$ \\
\hline & $\begin{array}{l}\text { Maximum evapotranspiration } \\
\left(E_{\max }\right)\end{array}$ & $\mathrm{m} \mathrm{d}^{-1}$ & $3.7 \times 10^{-3}$ & $4.76 \times 10^{-3}$ \\
\hline & $\begin{array}{l}\text { Evapotranspiration wilting point } \\
\left(E_{w}\right)\end{array}$ & $\mathrm{m} \mathrm{d}^{-1}$ & $10^{-4}$ & $1.3 \times 10^{-4}$ \\
\hline & Hygroscopic point $\left(s_{h}\right)$ & - & 0.04 & 0.14 \\
\hline & Point of incipient stress $\left(s^{*}\right)$ & - & 0.16 & 0.37 \\
\hline & Wilting point $\left(s_{w}\right)$ & - & 0.05 & 0.17 \\
\hline \multicolumn{5}{|c|}{ Modelled scenarios } \\
\hline \multicolumn{2}{|c|}{ Scenario $A \mathrm{I}$} & icultural & oil with climatic season & \\
\hline \multicolumn{2}{|c|}{ Scenario BI } & \multicolumn{3}{|c|}{ Agricultural soil without seasonality } \\
\hline \multicolumn{2}{|c|}{ Scenario AII } & \multicolumn{3}{|c|}{ Forest soil with climatic seasonality } \\
\hline \multicolumn{2}{|c|}{ Scenario BII } & \multicolumn{3}{|c|}{ Forest soil without seasonality } \\
\hline
\end{tabular}


Table 4. Parameters related to carbon and nitrogen soil dynamics used in all model scenarios. Shaded parameters correspond to variables that are not focused upon in this manuscript. Their details can be found in Porporato et al. (2003).

\begin{tabular}{|c|c|c|c|}
\hline Initial soil moisture & $s$ & - & 0.15 \\
\hline $\mathrm{C}$ litter pool & $C_{l}$ & $\mathrm{~g} \mathrm{~m}^{-3}$ & 1200 \\
\hline C humus pool & $C_{h}$ & $\mathrm{~g} \mathrm{~m}^{-3}$ & 8500 \\
\hline $\mathrm{C}$ biomass pool & $C_{b}$ & $\mathrm{~g} \mathrm{~m}^{-3}$ & 50 \\
\hline $\mathrm{N}$ ammonium pool & $N^{+}$ & $\mathrm{g} \mathrm{m}^{-3}$ & 0 \\
\hline $\mathrm{N}$ nitrate pool & $N$ & $\mathrm{~g} \mathrm{~m}^{-3}$ & 1 \\
\hline Added litter & Add & $\mathrm{gC} \mathrm{m}^{-3} \mathrm{~d}^{-1}$ & 1.5 \\
\hline $\mathrm{C} / \mathrm{N}$ ratio of added litter & $(C / N)_{a d d}$ & - & 58 \\
\hline $\mathrm{C} / \mathrm{N}$ ratio of litter & $(C / N)_{l}$ & - & 22 \\
\hline $\mathrm{C} / \mathrm{N}$ ratio of humus & $(C / N)_{h}$ & - & 22 \\
\hline $\mathrm{C} / \mathrm{N}$ ratio of microbial biomass & $(C / N)_{b}$ & - & 11.5 \\
\hline $\mathrm{C} / \mathrm{N}$ ratio of ammonium & $(C / N)^{+}$ & - & 1 \\
\hline $\mathrm{C} / \mathrm{N}$ ration of nitrate & $(C / N)^{-}$ & - & 1 \\
\hline Isohumic coefficient & $r_{h}$ & - & 0.25 \\
\hline Respiration coefficient & $r_{r}$ & - & 0.6 \\
\hline Litter decomposition rate & $k_{l}$ & $\mathrm{~m}^{3} \mathrm{~d}^{-1} \mathrm{gC}^{-1}$ & $6.5 \times 10^{-5}$ \\
\hline Factor of carbon return to litter pool & $k_{d}$ & $\mathrm{~d}^{-1}$ & $8.5 \times 10^{-3}$ \\
\hline Humus decomposition rate & $k_{h}$ & $\mathrm{~m}^{3} \mathrm{~d}^{-1} \mathrm{gC}^{-1}$ & $2.5 \times 10^{-6}$ \\
\hline Rate of nitrification & $k_{n}$ & $\mathrm{~m}^{3} \mathrm{~d}^{-1} \mathrm{gN}^{-1}$ & 0.6 \\
\hline Ammonium immobilization coefficient & $k_{\text {amm }}$ & $\mathrm{m}^{3} \mathrm{~d}^{-1} \mathrm{gN}^{-1}$ & 1 \\
\hline Nitrate immobilization coefficient & $k_{n i t}$ & $\mathrm{~m}^{3} \mathrm{~d}^{-1} \mathrm{gN}^{-1}$ & 1 \\
\hline Ammonium plant demand & $D E M^{+}$ & $\mathrm{gN} \mathrm{m}^{-3} \mathrm{~d}^{-1}$ & 0.2 \\
\hline Nitrate plant demand & $D E M$ & $\mathrm{gN} \mathrm{m}^{-3} \mathrm{~d}^{-1}$ & 0.5 \\
\hline Fraction of dissolved ammonium & $a^{+}$ & - & 0.05 \\
\hline Fraction of dissolved nitrate & $a^{-}$ & - & 0.1 \\
\hline
\end{tabular}




\section{Figures}

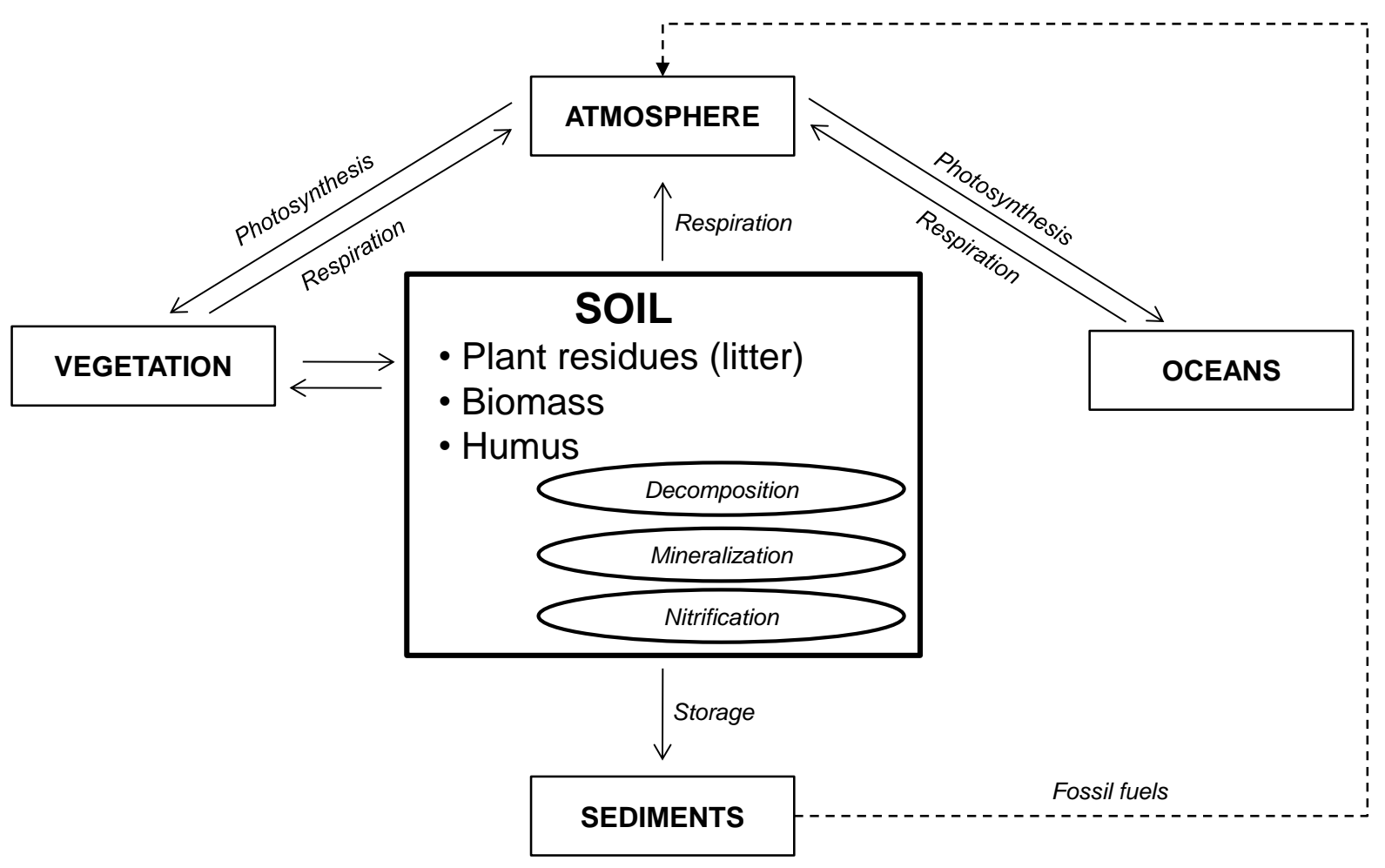

Figure 1. Simplified representation of the global carbon cycle. 


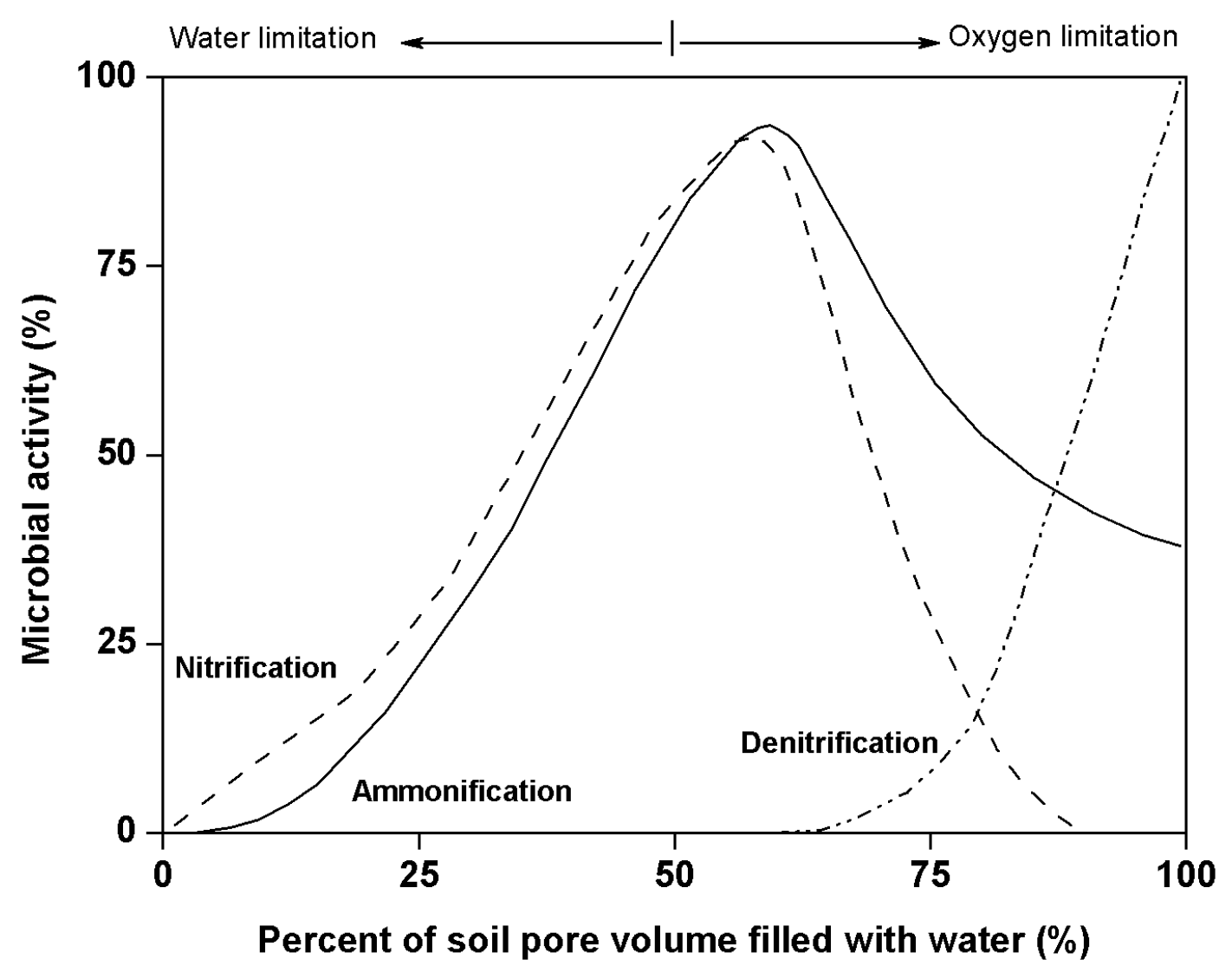

Figure 2. Influence of the soil water content on bacterial activity in different processes of nitrogen transformations (after Fenchel et al., 1998). 


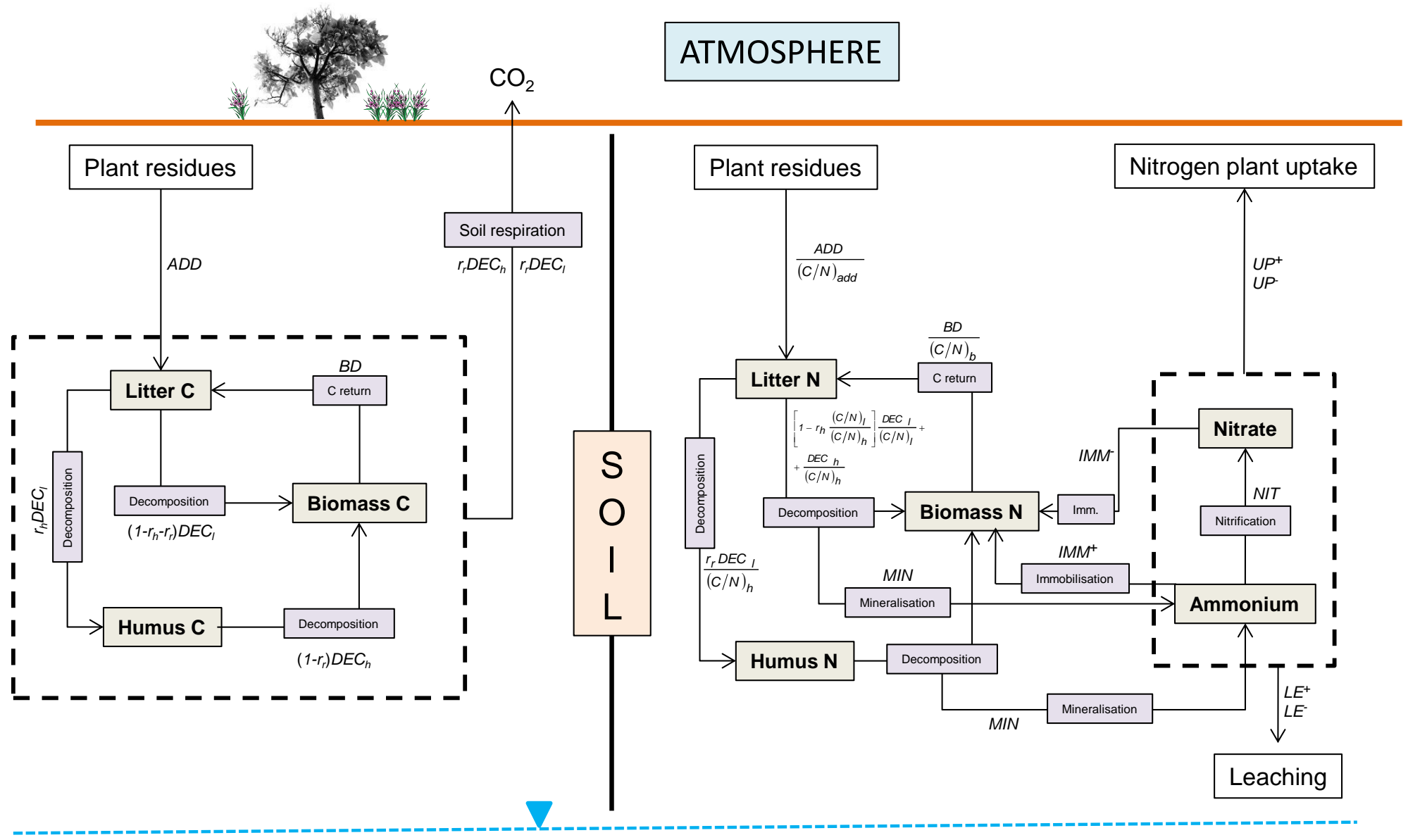

\section{AQUIFER}

2 Figure 3. Schematic representation of soil $\mathrm{C}$ and N cycles (after Rodriguez-Iturbe and Porporato, 2004). 

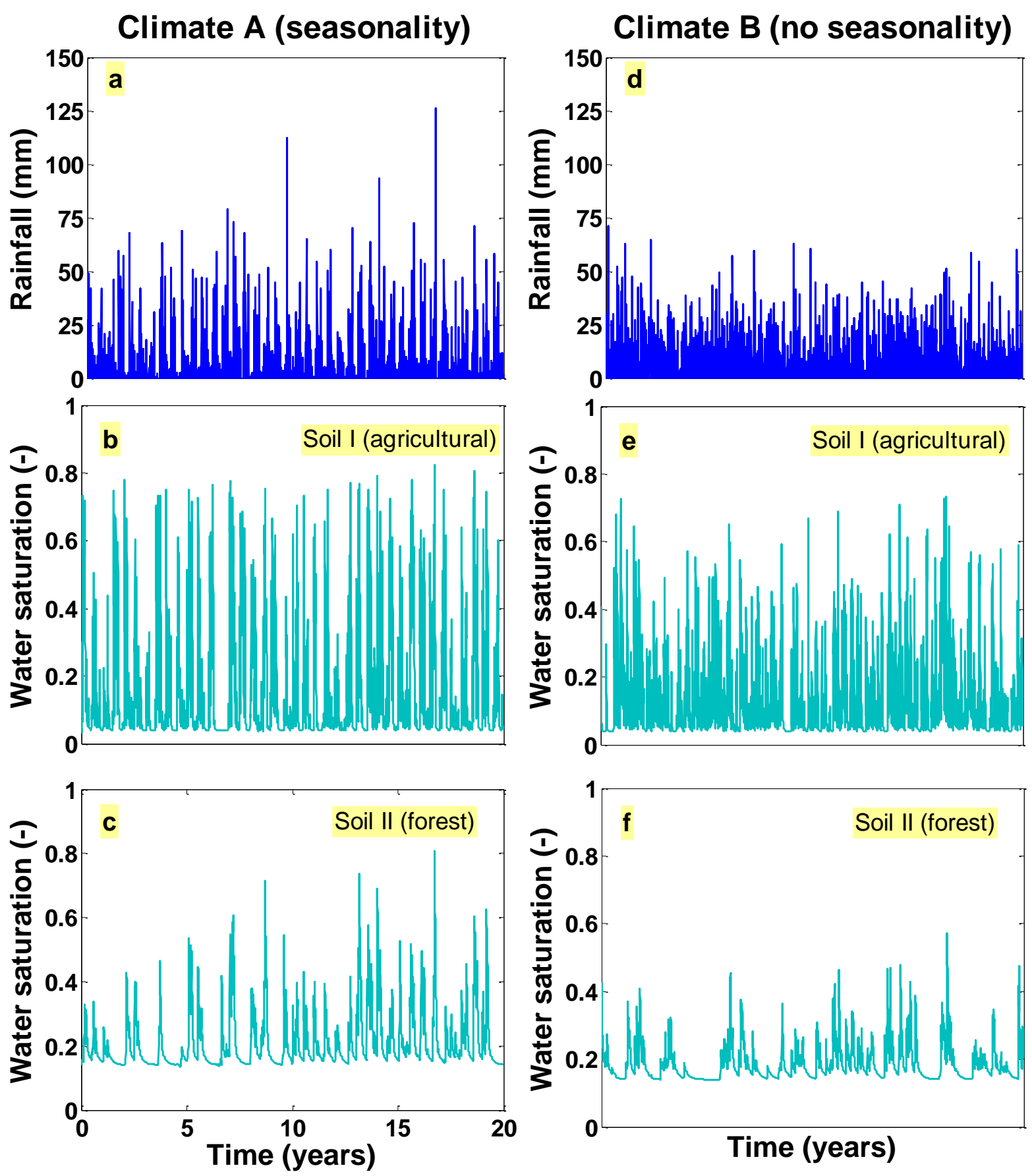

4 Figure 4. Simulated rainfall and corresponding water saturation of climate $A$ (with seasonal effects) and climate $B$ (without seasonal effects) for idealized agricultural (a, b and c) and forest (d, e and f) soils. 

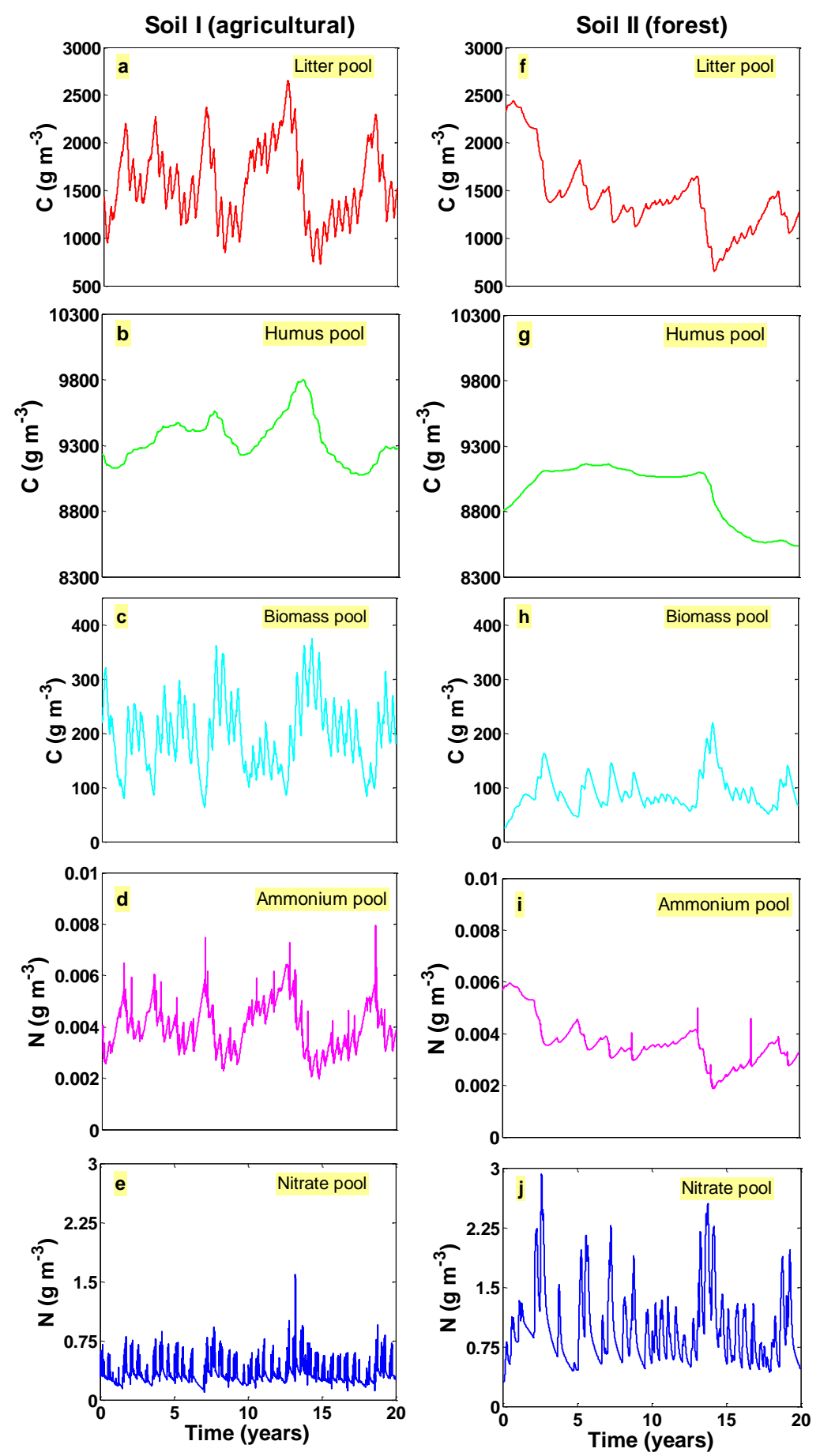

8 Figure 5. Simulated organic carbon and inorganic nitrogen concentrations for agricultural (left

9 side) and forest (right side) soils under climate $A$ conditions. 

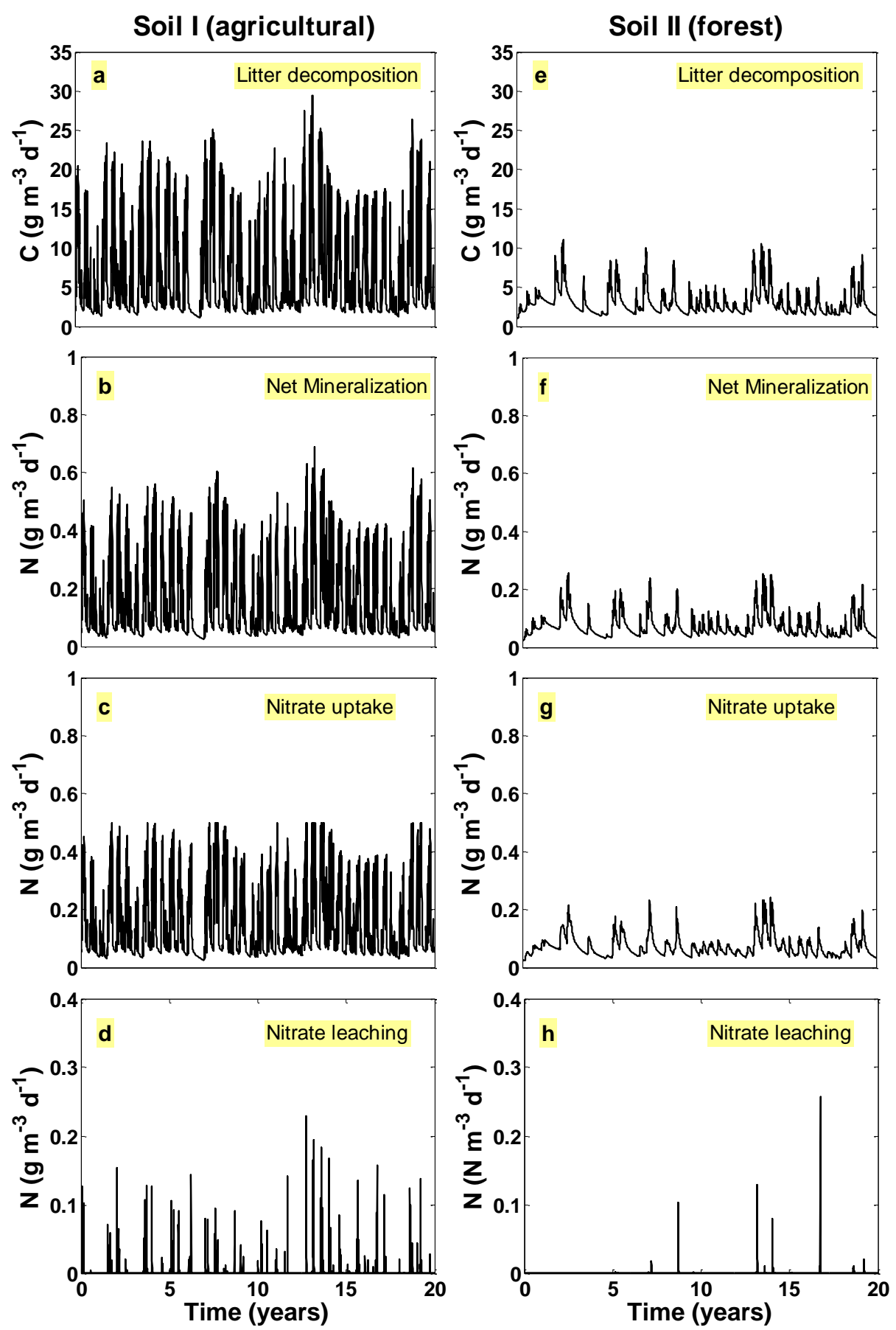

11 Figure 6. Simulated rates of litter decomposition (a, e), net nitrogen mineralization (b, f), nitrate uptake (c, g) and nitrate leaching (d, h) for both agricultural and forest soils under climate $A$ conditions. 

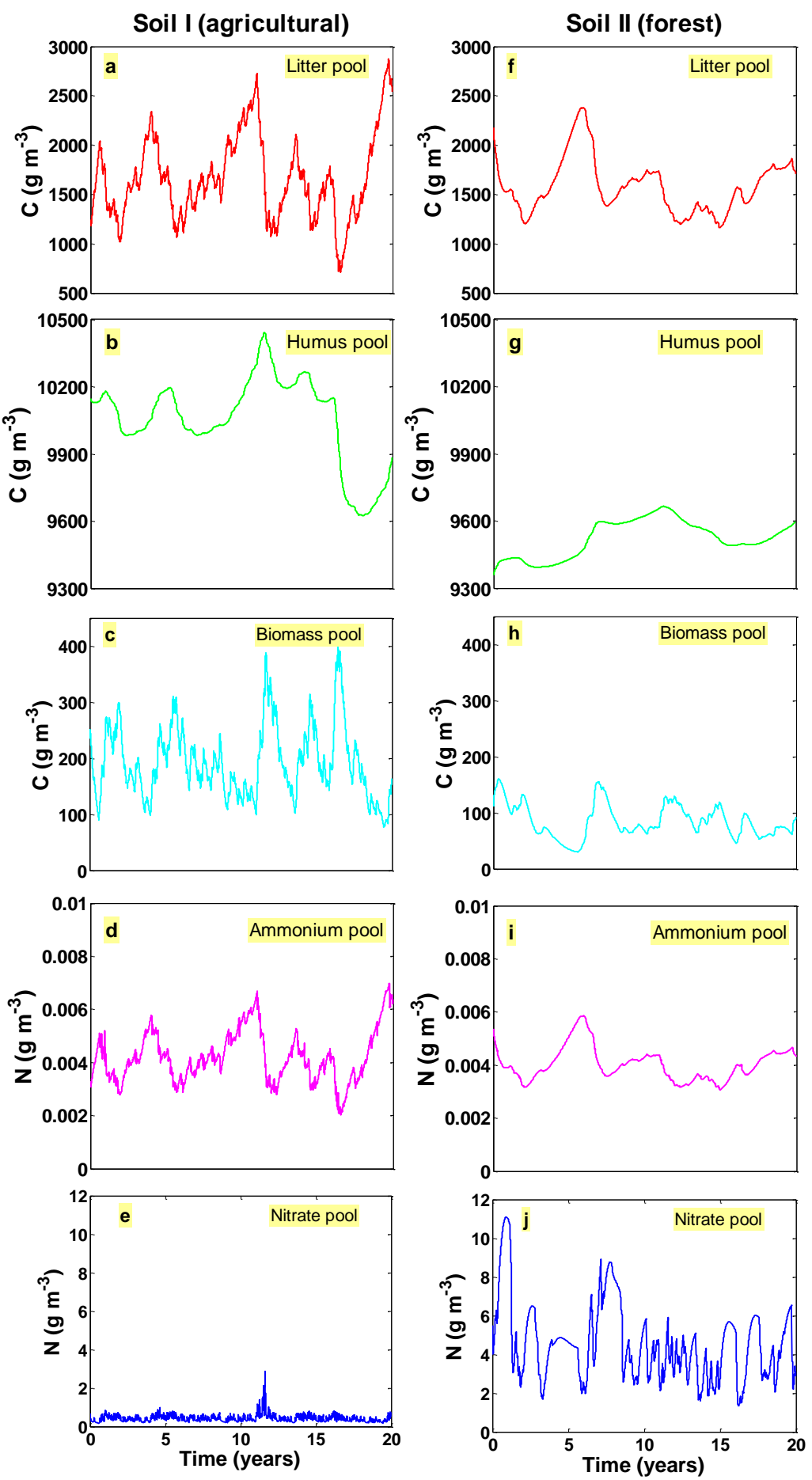

15 Figure 7. Simulated organic carbon and inorganic nitrogen concentrations for agricultural (left side) and forest (right side) soils under climate $B$ conditions. 

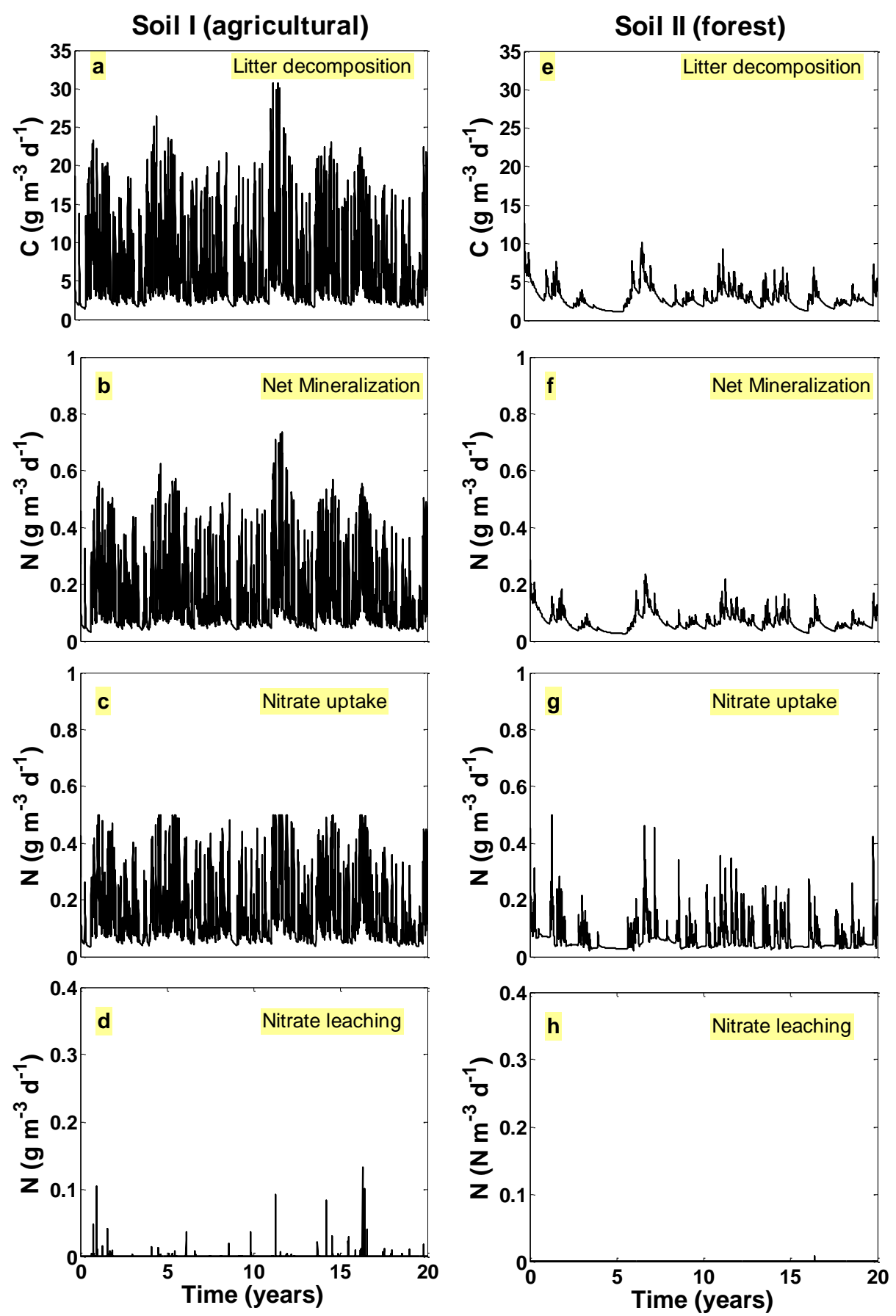

18 Figure 8. Simulated rates of litter decomposition (a, e), net nitrogen mineralization (b, f), nitrate

19 uptake (c, g) and nitrate leaching (d, h) for both agricultural and forest soils under climate $B$ condi20 tions. 